
$\angle$ Research Square
Preprints are preliminary reports that have not undergone peer review.
They should not be considered conclusive, used to inform clinical practice,
or referenced by the media as validated information.

\title{
Deciphering Higher Order Non-Allelic Interactions For Quantitative Characters Through Twelve Generation Mean Analysis In Castor (Ricinus Communis L.)
}

Kiran Mori ( $\nabla$ kirankmori@gmail.com )

Junagadh Agricultural Univertsity https://orcid.org/0000-0003-0078-5066

Jagdish Patel

Junagadh Agricultural Univertsity

Kirti Rani

Directorate of Groundnut Research (DGR)

Vaishali Mori

Junagadh Agricultural Univertsity

Mithlesh Kumar

S.D. Agricultural University

BC Ajay

Directorate of Groundnut Research (DGR)

\section{Research Article}

Keywords: Castor, genetic architecture, generation mean, epistasis and oil content

Posted Date: November 29th, 2021

DOI: https://doi.org/10.21203/rs.3.rs-892916/v1

License: (c) (1) This work is licensed under a Creative Commons Attribution 4.0 International License. Read Full License

Version of Record: A version of this preprint was published at Genetic Resources and Crop Evolution on January 26th, 2022. See the published version at https://doi.org/10.1007/s10722-021-01339-6. 


\section{Abstract}

The genetic architecture of oil content, seed yield and its related biometric traits in castor was investigated through generation mean analysis of four crosses viz., JP 104 x JI 433, SKP 84 x JI 433, SKP 84 x JI 437 and SKP 84 x JI 441 in twelve generations $\left(\mathrm{P}_{1}, \mathrm{P}_{2}, \mathrm{~F}_{1}, \mathrm{~F}_{2}, \mathrm{~B}_{1}, \mathrm{~B}_{2}, \mathrm{~B}_{11}, \mathrm{~B}_{12}, \mathrm{~B}_{21}, \mathrm{~B}_{22}, \mathrm{~B}_{1 \mathrm{~s}}\right.$ and $\left.\mathrm{B}_{2 \mathrm{~s}}\right)$ Significance of simple scaling tests and Cavali's joint scaling test in all the crosses for one or more traits indicated the presence of digenic and trigenic gene interactions. Further, the significant $\chi^{2}{ }_{(2)}$ value at six degrees of freedom based on six-parameter model of Hill (1966), depicted the presence of trigenic or higher order epistasis in all the crosses for all the characters. The trigenic ten-parameter model was found to be adequate in cross JP $104 \mathrm{x} J \mathrm{~J} 433$ for effective length of primary raceme; in crosses JP 104 x JI 433 and SKP 84 x JI 437 for number of capsules on primary raceme; and in cross SKP 84 x JI 441 for number of effective branches per plant. On the other hand, $\chi^{2}{ }_{(3)}$ with two degrees of freedom was found significant for remaining traits in all the four crosses showing the presence of higher order epistasis and/or linkage. All the ten-parameters were significant for shelling out turn percentage in three crosses SKP $84 \mathrm{X} \mathrm{JI} 433$, SKP 84 x JI 437 and SKP 84 x JI 441 and for days to maturity of primary raceme in cross SKP 84 x JI 433. Moreover, the duplicate epistasis was reported for the inheritance of oil content, seed yield and its component traits. This information can be utilized in developing castor lines with high seed yield and oil content.

\section{Introduction}

Castor (Ricinus communis L., $2 \mathrm{n}=20$ ) is an important non-edible oilseed crop that belongs to the family Euphorbiaceae. Castor is indigenous to Eastern Africa and most probably originated in Ethiopia. It is generally distributed in the tropical, sub-tropical and warm temperate zones (Weiss 2000). India is the world's principal producer of castor and ranks first in both area and production. Castor productivity in India is more than world average and it ranks first among the major castor producing countries. The area, production and productivity of castor in India during 2017-18 were 11.10 lakh hectares, 17.75 lakh tonnes and $1599 \mathrm{~kg} / \mathrm{ha}$, respectively (Anonymous 2017). In Gujarat, 14.40 lakh tonnes of castor seed were produced from an area of 7.70 lakh hectares with an average productivity of $1870 \mathrm{~kg} / \mathrm{ha}$ during 2017-18 (Anonymous 2017). It is cultivated around the world because of commercial importance of its oil. Because of its ability to remain liquid at extremely low temperatures $\left(-32^{\circ} \mathrm{C}\right)$, high density and viscosity, the oil is mostly employed as a lubricant. Castor oil and its derivatives are mainly used to make lubricants, polymers, adhesives, waxes, polishes, coating applications, inks, and paints. Because a crop's seed output is determined by the interplay of numerous genes with the environment, direct selection will not be successful. So, selection for yield components has been suggested as a solution for further genetic gain in yield. An understanding of mode of inheritance of all the component characters to be selected for genetic improvement is necessary for the intelligent choice of efficient breeding procedures for developing high yielding varieties. One of the best methods for the estimation of genetic parameters is generation mean analysis, in which nonallelic genic interactions could also be estimated.

Genetic analysis of quantitative traits further helps to elucidate the nature and magnitude of genetic variation present in the population. The estimates of gene effects have a direct bearing upon the choice of breeding procedure to be followed. Generation mean analysis is an efficient tool to understand the nature of gene effects involved in the expression of the character. Information on nature and relative magnitude of genetic component of variation (additive and dominance) have been elucidated by diallel or lines $\mathrm{x}$ tester analysis in castor, which unlike generation mean analysis as does not provide information on nonallelic gene actions operating in the inheritance of the traits. The non-allelic interaction could inflate the measure of additive and dominance components. It is, therefore, important to estimate the components of epistasis along with the additive and dominance components of genetic variation. However, generation mean analysis has been extensively used to understand the gene effects in different crops, but very few reports are available on the use of this technique for dissecting the gene effects in castor crop. As Patel et al (2021) revealed that additive as well as non-additive gene effects were observed for wilt incidence and seed yield in all the six crosses of castor. Furthermore, information on gene effects, particularly higher order epistasis, influencing yield and its attributes in castor is limited. Keeping in view, the present investigation was made to estimate the nature and magnitude of gene effects for oil content, yield and its components using 12 generations of four cross combinations and 10-parameter model (Hill 1966).

\section{Materials And Methods}

\section{Experimental materials and location}

The experimental material comprised of four crosses viz., JP 104 x JI 433, SKP 84 x JI 433, SKP 84 x JI 437 and SKP 84 x JI 441 among five castor genotypes and each cross with twelve generations viz., $P_{1}, P_{2}, F_{1}, F_{2}, B_{1}, B_{2}, B_{1 S}, B_{11}, B_{12}, B_{2 S}, B_{21}$ and $B_{22}$. The parents of were selected from diverse genetic stocks available at the Main Oilseeds Research Station, Junagadh Agricultural University, Junagadh, Gujarat (Table 1). Experiment was conducted at Sagdividi Farm, Department of Seed Science and Technology, College of Agriculture, Junagadh Agricultural University, Junagadh, South Saurashtra situated at 21.5 $\mathrm{N}$ latitude and $70.5^{\circ} \mathrm{E}$ longitude with an altitude of 60 meter above the mean sea level. The soil of experimental plot was medium black.

Field experiment and observations recorded

The basic set of twelve generations viz., $P_{1}, P_{2}, F_{1}, F_{2}, B_{1}\left(F_{1} \times P_{1}\right), B_{2}\left(F_{1} \times P_{2}\right), B_{1 S}\left(B_{1}\right.$ selfed $), B_{11}\left(B_{1} \times P_{1}\right), B_{12}\left(B_{1} \times P_{2}\right), B_{2 S}\left(B_{2}\right.$ selfed), $B_{21}\left(B_{2} \times P_{1}\right)$ and $B_{22}$ $\left(B_{2} \times P_{2}\right)$ derived from four crosses were sown in compact family block design (CFBD) with three replications of each during Kharif 2017-18. Each replication consisted of four compact blocks and each block consisted of one particular cross. Further each block consisted of twelve plots for each of twelve generations of each cross. The crosses were assigned to each block and twelve generations of a cross were randomly allotted to individual plot within the block. The plots of various generations were sown in different number of rows i.e., parents and $F_{1}$ in single row; $B_{1}$ and $B_{2}$ in three rows; and $F_{2}$, $B_{11}, B_{12}, B_{21}$, $B_{22}, B_{1 S}$ and $B_{2 S}$ in five rows each. Each row was of $6.0 \mathrm{~m}$ length with 120 and $45 \mathrm{~cm}$ inter and intra row spacing, respectively. All the recommended agronomical practices and necessary plant protection measures were followed to raise a good crop. The observations were recorded on individual plant basis in each replication on randomly selected five plants from $P_{1}, P_{2}$ and $F_{1}$; fifteen plants from first backcross $\left(B_{1}\right.$ and $\left.B_{2}\right)$ and twenty-five plants of $F_{2}$, $B_{1}$, $B_{11}$, 
$B_{12}, B_{2 S}, B_{21}, B_{22}$ generations for seed yield its components traits (days to flowering of primary raceme, days to maturity of primary raceme, plant height up to primary raceme $(\mathrm{cm})$, number of capsules on primary raceme, shelling out turn (\%), 100 seed weight (g) and oil content (\%). The inheritance of all the characters studied was computed through generation mean analysis methods (Mather 1949; Hayman and Mather 1955; Hayman 1958 and Hill 1966).

Statistical and genetical analysis

The data obtained for yield, component traits and oil content were subjected to analysis of variance using Indostat 8.5 software (2004) according to compact family block design (Panse and Sukhatme1978). The significance of the test genotypes was assessed using the $F$ probabilities at $P<0.05$. The mean values for each trait were computed from 5 competitive individual plants of $P_{1}, P_{2}$ and $F_{1} ; 15$ plants of $B_{1}$ and $B C_{2}$ and 25 plants for $F_{2}, B_{1 S}, B_{11}, B_{12}, B_{2 S}, B_{21}, B_{22}$ generations for each replicate. The replication-wise mean values of different generations for each individual character were calculated using Excel program. $A$ Tukey's Honest Significant Difference (Tukey's HSD) test (Tukey 1977) was applied to assess the mean difference between different traits and among generations at $P \leq 0.05$ using R statistical software, version 3.4.1 (R Development Core Team 2018). The crosses showing significant differences among the entries (progenies) for different characters were subjected to generation mean analysis for estimation of gene effects using different models (Mather, 1949; Hayman and Mather, 1955; Hayman, 1958 and Hill, 1966). The data was initially subjected to simple scaling tests $A, B, C$ and $D$ to check the adequacy of additive dominance model for different traits from each cross. Further, simple scaling tests $B_{11}, B_{12}, B_{21}, B_{22}, B_{1 s}$ and $B_{2 s}$ (Hill, 1966) and $X$ and $Y(V a n$ der Veen 1959) were computed. Significant estimates of the tests given by Hill (1966) showed contribution of particular generation to higher order epistasis which is indirectly indicating presence of epistasis. If any of the Van der Veen's tests significantly deviates from zero, it also indicates presence of trigenic or higher order epistasis. The results of simple scaling tests were further confirmed by joint scaling test (Cavalli 1952), which effectively combines the whole set of simple scaling tests. Thus, it offers a more general, convenient, adoptable and informative approach for estimating gene effects and also for testing adequacy of additive-dominance model. The $\chi^{2}{ }_{(1)}$ of joint scaling test with nine degrees of freedom under three-parameter model gives idea about fitness of additivedominance model. Using six basic generations, six parameter model given by Hayman (1958) was also fitted. Finally, the data were subjected to ten-parameter model given by Hill (1966) which provided estimation of first order and second order epistasis utilizing twelve generations including double backcross generations. The $\chi^{2}{ }_{(2)}$ and $\chi^{2}{ }_{(3)}$ values were estimated under six-parameters model at six degrees of freedom and under ten-parameters model at two degrees of freedom, respectively. This is an additional advantage of using twelve generations and ten-parameter model as it provides sufficient degree of freedom for testing validity and goodness of fit for different models.

\section{Results}

Analysis of variance and per se performance

The analysis of variance for all the twelve characters studied in each of four crosses is presented in Table 2. The analysis of mean sum of squares between families (crosses) were significant for all the characters studied in all the crosses except for oil content indicating the presence of genetic variability for different traits. The Bartlett's test for homogeneity of error variances of four crosses indicated that the error variances were homogenous for days to flowering of primary raceme, days to maturity of primary raceme, plant height up to primary raceme, number of nodes up to primary raceme, 100 seed weight and seed yield per plant as these traits showed non-significance chi-square values. Since, the crosses revealed significant mean sum of squares among different generations for different characters so, further analyzed for per se performance and gene action. The mean values of various quantitative traits in different generations from four crosses are depicted in Fig.1. The performance of $F_{1}$ hybrids exceeded the value of their better parent in positive direction for days to flowering of primary raceme, days to maturity of primary raceme in all four crosses; for length of primary raceme and effective length of primary raceme in JP 104 x JI 433 and SKP 84 x JI 441; for number of effective branches per plant and 100 seed weight in SKP 84 x JI 441; for plant height up to primary raceme and oil content in JP 104 x JI 433 and SKP 84 x JI 433; for number of nodes up to primary raceme in SKP 84 x JI 433 , SKP 84 x JI 437 and SKP 84 x JI 441 ; and number of capsules on primary raceme and shelling out turn in SKP 84 x J 437 . None of the $\mathrm{F}_{1}$ exceeded the seed yield per plant over their better parent in positive direction. Similarly, none of the $F_{1}$ was poorer than its respective poor parent for all the crosses except for number of nodes up to primary raceme in cross JP 104 x JI 433; effective length of primary raceme in cross SKP 84 x JI 437 and SJP 84 x JI 433; seed yield per plant in SKP 84 x JI 437 ; and oil content in SKP 84 x JI 437 and SKP 84 x JI 441. With respect to days to flowering of primary raceme, days to maturity of primary raceme, plant height up to primary raceme and number of nodes up to primary raceme, parents with low value/per se was considered as better parent, in which the per se performance of $F_{1}$ was lower than its better parent for plant height up to primary raceme in crosses SKP 84 x JI 437 and SKP 84 x JI 441 and for number of nodes up to primary raceme in cross JP $104 \times \mathrm{JI} 433$, while for days to flowering of primary raceme and days to maturity of primary raceme, none of the $\mathrm{F}_{1}$ per se was lower than its better parent. Further, none of the $F_{1}$ exceeded the seed yield per plant over their better parent in positive direction. Similarly, none of the $F_{1}$ was poorer than its respective poor parent for all the crosses except for number of nodes up to primary raceme in cross JP $104 \times$ JI 433 ; effective length of primary raceme in cross SKP 84 x JI 437 and SKP 84 x JI 433; seed yield per plant in SKP 84 x JI 437; and oil content in SKP 84 x JI 437 and SKP 84 x JI 441 . The mean values of various quantitative traits in different generations from nine crosses are depicted in the Fig.1.

\section{Scaling tests and estimation of gene effects}

Estimates of scaling tests

Initially, the data were subjected to simple scaling tests A, B, C and D (Table 3 to 14). Significant estimates of one or more of these tests for all the traits in all the crosses except for plant height up to primary raceme in cross SKP 84 x JI 441 indicated the presence of digenic interactions (Table 5). Significance of one or other scaling tests $B_{11}, B_{12}, B_{21}, B_{22}, B_{1 s}$ and $B_{2 s}$ and $X$ and $Y$ for different traits in almost all crosses indicating the importance of higher order interactions. The scaling test $B_{12}$ and $Y$ for plant height up to primary raceme; $B_{12}$ and $B_{21}$ for length of primary raceme; $B_{12}, B_{21}, B_{22}$ and $X$ for effective length of primary 
raceme; $B_{21}$ for number of capsules on primary raceme; $B_{22}$ for shelling out turn; $B_{21}$ and $X$ for 100 seed weight; $B_{11}, B_{12}, B_{21}, B_{22}, B_{1 s}, X$ and $Y$ for seed yield per plant and $\mathrm{B}_{12}, \mathrm{~B}_{21}, \mathrm{~B}_{1 \mathrm{~s}}$ and $\mathrm{B}_{2 \mathrm{~s}}$ for oil content were significant in all the four crosses.

Estimates of gene effects

The estimates of ' $m$ ' were significant in all four crosses for all the traits studied (Table 3 to 14). The additive [d] gene effect was significant and negative in cross JP 104 x Jl 433 for days to maturity of primary raceme, plant height up to primary raceme, number of nodes up to primary raceme, number of effective branches per plant, number of capsules on primary raceme and 100 seed weight; in cross SKP 84 x JI 433 for length of primary raceme, effective length of primary raceme, number of effective branches per plant and number of capsules on primary raceme; in cross SKP 84 x JI 437 for plant height up to primary raceme, length of primary raceme, shelling out turn, 100 seed weight and seed yield per plant; and in cross SKP 84 x JI 441 for plant height up to primary raceme. On the other hand, the additive [d] gene effect was observed significant and positive in cross JP 104 x JI 433 for days to flowering of primary raceme, length of primary raceme and seed yield per plant; in cross SKP 84 x JI 433 for days to flowering of primary raceme, days to maturity of primary raceme, plant height up to primary raceme, shelling out turn, seed yield per plant and oil content; in cross SKP 84 x JI 437 for days to flowering of primary raceme, days to maturity of primary raceme, number of nodes up to primary raceme, number of capsules on primary raceme and oil content; and in cross SKP $84 \mathrm{x} J \mathrm{I} 44 \mathrm{for}$ days to flowering of primary raceme, length of primary raceme, effective length of primary raceme, shelling out turn, 100 seed weight and seed yield per plant. The dominance [h] gene effect played important role for inheritance of days to flowering of primary raceme, length of primary raceme, effective length of primary raceme, shelling out turn, 100 seed weight, seed yield per plant and oil content in all four crosses viz., JP 104 x JI 433 , SKP 84 x JI 433 , SKP 84 x JI 437 and SKP 84 x JI 441; of days to maturity of primary raceme, plant height up to primary raceme and number of effective branches per plant in crosses JP 104 x JI 433, SKP 84 x JI 433 and SKP 84 x JI 437; of number of nodes up to primary raceme in crosses JP 104 x JI 433 and SKP 84 x JI 437 ; and of number of capsules on primary raceme in two crosses JP 104 x JI 433 and SKP 84 x JI 441. When the simple additive-dominance model failed to explain the variation among generation means, a six-parameter model involving three digenic interactions ([i], [j] and [l]) proposed by Hayman (1958) was applied. This model utilized only six basic generation viz., $\mathrm{P}_{1}, \mathrm{P}_{2}, \mathrm{~F}_{1}, \mathrm{~F}_{2}, \mathrm{~B}_{1}$ and $\mathrm{B}_{2}$. On the other hand, based on weighted least square technique, digenic and trigenic interaction models were also tested which had additional provision of testing the adequacy of model with six degrees of freedom and two degrees of freedom besides being utilizing means of all the twelve generations, respectively. Further, these models were not adequate for all the traits studied in four crosses in the present study. The significant of $\chi^{2}{ }^{2}$ (2) value at six degrees of freedom pointed out the presence of higher order gene interactions in all four crosses for all the traits studied. The goodness of fit for six-parameter model of Hayman (1958) could not be tested in the present study owing to no degrees of freedom left for testing chi-square estimates for various characters. Therefore, the perfect fit solution of Hayman (1958) does not provide a general method for testing the adequacy of digenic interaction model. Such a method would require experiment with more number of family means than the minimum number necessary for fitting a full digenic interaction model. Hence, the present study was planned and executed with means of twelve generations and model of Hill (1966) was tested in which six degrees of freedom left for testing the adequacy of six-parameter model of Hill (1966). While fitting trigenic epistatic model, the $\chi^{2}{ }^{2}$ (3) value at two degrees of freedom were non-significant for effective length of primary raceme in JP $104 \mathrm{x}$ JI 433; for number of effective branches per plant in SKP 84 x JI 441; for number of capsules on primary raceme in two crosses namely, JP 104 x JI 433 and SKP 84 x JI 437 suggesting the adequacy of the trigenic interaction model.

Among digenic interactions, additive $x$ additive [i] gene effect was significant in all four crosses for length of primary raceme and shelling out turn; in crosses SKP 84 x JI 433, SKP 84 x JI 437 and SKP 84 x JI 441 for effective length of primary raceme and seed yield per plant; in crosses JP 104 x JI 433 , SKP 84 x JI 437 and SKP 84 x JI 441 for number of capsules on primary raceme and oil content; in crosses JP 104 x JI 433 , SKP 84 x JI 433 and SKP 84 x JI 441 for 100 seed weight; in crosses SKP 84 x Jl 433 and SKP 84 x JI 437 for days to maturity of primary raceme and number of effective branches per plant; in crosses JP 104 x JI 433 and SKP 84 x JI 437 for number of nodes up to primary raceme; in cross SKP 84 x Jl 441 for days to flowering of primary raceme and in cross SKP 84 x Jl 437 for plant height up to primary raceme.

Likewise, the estimates of additive $x$ dominance [j] gene effect were significant for days to maturity of primary raceme, shelling out turn, seed yield per plant and oil content in all four crosses, JP 104 x JI 433, SKP 84 x JI 433, SKP 84 x JI 437 and SKP 84 x JI 441; for days to flowering of primary raceme in crosses JP 104 x JI 433, SKP 84 x JI 433 and SKP 84 x JI 441; for plant height up to primary raceme and 100 seed weight in crosses JP 104 x JI 433 , SKP 84 x JI 437 and SKP 84 x JI 441; for length of primary raceme and number of capsules on primary raceme in JP 104 x JI 433 , SKP 84 x JI 433 and SKP 84 x JI 437 ; for number of nodes up to primary raceme in crosses JP 104 x JI 433 and SKP 84 x JI 437; for effective length of primary raceme in crosses JP 104 x JI 433 and SKP 84 x JI 433; and for number of effective branches per plant in cross JP 104 x JI 433.

Similarly, dominance $x$ dominance [I] gene effect was observed significant for days to flowering of primary raceme, effective length of primary raceme, number of effective branches per plant, shelling out turn and 100 seed weight in all four crosses JP 104 x JI 433, SKP 84 x JI 433 , SKP 84 x JI 437 and SKP 84 x JI 441 ; for days to maturity of primary raceme, plant height up to primary raceme and seed yield per plant in crosses JP $104 \times$ JI 433 , SKP $84 \times$ JI 433 and SKP 84 x JI 437; for length of primary raceme in crosses SKP 84 x JI 433, SKP 84 x JI 437 and SKP 84 x JI 441; for number of nodes up to primary raceme in crosses JP 104 x JI 433 and SKP 84 x JI 437; for number of capsules on primary raceme in crosses JP 104 x JI 433 and SKP 84 x JI 441 ; and for oil content in crosses SKP 84 x JI 433 and SKP 84 x JI 441. This indicated that digenic epistasis interactions had also contributed a sizeable portion of variation in the genetic makeup of various traits.

Trigenic epistasis was significant in various crosses for different characters in the present study. Additive $\mathrm{x}$ additive $\mathrm{x}$ additive [w] gene effect was observed significant in the present study in all four crosses for plant height up to primary raceme, length of primary raceme, shelling out turn and seed yield per plant; in crosses JP 104 x JI 433, SKP 84 x JI 433 and SKP 84 x JI 437 for days to maturity of primary raceme and number of capsules on primary raceme; in crosses JP 104 x JI 433, SKP 84 x JI 433 and SKP 84 x JI 441 for days to flowering of primary raceme; in crosses JP 104 x JI 433 , SKP 84 x JI 437 and SKP 84 x JI 441 for 100 seed weight; in crosses JP 104 x JI 433 and SKP 84 x JI 433 for number of effective branches per plant; in crosses SKP 84 x JI 433 and SKP 84 x 
JI 441 for effective length of primary raceme; in crosses SKP 84 x JI 433 and SKP 84 x JI 437 for oil content; and in cross JP 104 x JI 433 for number of nodes up to primary raceme.

Moreover, additive $\mathrm{x}$ additive $\mathrm{x}$ dominance $[\mathrm{x}]$ gene effect was significant for number of capsules on primary raceme, shelling out turn and 100 seed weight in all four crosses JP 104 x JI 433, SKP 84 x JI 433, SKP 84 x JI 437 and SKP 84 x JI 441; for days to flowering of primary raceme in crosses SKP 84 x JI 433 , SKP 84 x JI 437 and SKP 84 x JI 441; for number of effective branches per plant and oil content in crosses JP 104 x JI 433 , SKP 84 x JI 433 and SKP 84 x JI 441; for length of primary raceme in crosses JP 104 x JI 433, SKP 84 x JI 433 and SKP 84 x JI 437; for seed yield per plant in crosses JP 104 x JI 433 , SKP 84 x JI 437 and SKP 84 x JI 441; for days to maturity of primary raceme, plant height up to primary raceme and effective length of primary raceme in crosses SKP 84 x JI 433 and SKP 84 x JI 437; and for number of nodes up to primary raceme in crosses JP 104 x JI 433 and SKP 84 x JI 441.

On the other hand, additive $x$ dominance $x$ dominance $[y]$ gene effect was significant for plant height up to primary raceme, length of primary raceme, shelling out turn and oil content in all the four crosses, for days to maturity of primary raceme, number of nodes up to primary raceme, 100 seed weight and seed yield per plant in three crosses viz., JP 104 x JI 433, SKP 84 x JI 433 and SKP 84 x JI 437; for effective length up to primary raceme in crosses JP 104 x JI 433 , SKP 84 x JI 433 and SKP 84 x JI 441; for number of capsules on primary raceme in crosses JP 104 x JI 433, SKP 84 x JI 437 and SKP 84 x JI 441 ; for days to flowering of primary raceme in crosses, JP 104 x JI 433 and SKP 84 x JI 441; and for number of effective branches per plant in crosses JP 104 x JI 433 and SKP 84 x JI 437.

With respect to dominance $x$ dominance $x$ dominance $[z]$ gene effect, it was noted significant for days to flowering of primary raceme, shelling out turn, seed yield per plant and oil content in all the four crosses; for days to maturity of primary raceme, effective length up to primary raceme and number of effective branches per plant in three crosses viz., JP 104 x JI 433, SKP 84 x JI 433 and SKP 84 x JI 437; for number of capsules on primary raceme and 100 seed weight in crosses SKP 84 x JI 433, SKP 84 x JI 437 and SKP 84 x JI 441; for length of primary raceme in crosses SKP 84 x JI 433 and SKP 84 x JI 437 ; for plant height up to primary raceme in cross SKP 84 x Jl 437; and for number of nodes up to primary raceme in cross JP $104 \times \mathrm{JI} 433$. So, to sum all types of digenic and trigenic interactions was found significant for shelling out turn in two crosses SKP 84 x JI 437 and SKP 84 x JI 441 and for days to maturity of primary raceme in cross SKP $84 \times \mathrm{JI} 433$.

The opposite signs of either two or all the three gene effects viz., dominance [h], dominance $\mathrm{x}$ dominance [l] and dominance $\mathrm{x}$ dominance $\mathrm{x}$ dominance [z] suggests the presence of duplicate type of epistasis. In the present study, duplicate epistasis was reported in all the crosses for all the characters studied when all the three gene effects were considered together. Further, considering only [h] and [l] parameters, two were opposite in all four crosses for all the traits studied except for days to maturity of primary raceme in cross JP 104 x JI 433, that further indicated involvement of largely duplicate type of gene action in the inheritance of seed yield and its component traits.

\section{Discussion}

For improvement of any trait, selection of parents on the basis of phenotypic performance alone may not necessarily lead to desirable results (Allard 1960). Phenotypically superior lines may yield poor recombinants in the segregating generations. It is, therefore, essential that parents should be chosen on the basis of their genotypic value. The genetic components of variation are helpful to decipher an overall genetic picture of quantitative characters. Hence, the knowledge of the genetics is essential for simultaneous improvement of different agro-morphological, yield and contributing traits as well as quality traits. Castor is a significant non-edible oil seeds crop of Gujarat state. Several breeding techniques have significantly enhanced the yield potential of this crop. The most promising and feasible breeding practice for boosting production and quality features that relies on the availability of genetic variation has been the exploitation of heterosis. In the present study mean sum of squares due to generations were significant in most of the crosses for different traits especially oil content indicating the presence of genetic diversity in the materials used for the study. Per se performance in $\mathrm{F}_{1}$ generations from different crosses indicated that most agronomical traits along with yield and oil-content were governed by partial dominance to overdominance gene actions. Thus, heterosis or recombination breeding or recurrent selection for specific combining ability (RSSCA) may be recommended for all the crosses that showed dominance or over dominance, while for crosses that evinced partial dominance, breeding methods involving high volume crossing to recover the good segregants like biparental mating, diallel selective mating (DSM) and reciprocal recurrent selection (RRS) etc. may be followed (Kumar et al. 2021). Further, generation mean studies showed the pre-ponderance of non allelic interactions with importance of predominantly duplicate gene actions for inheritance of yield, related traits studied along with oil content. Duplicate type of digenic interaction indicated greater genetic diversity for different traits studied in castor. Cockerham (1959) postulated that the epistasis gene action is more common in the inheritance of quantitative traits and there is no sound biological reason why this type of gene action should be less common for these traits. Mather (1943), Horner et al. (1955), Gilbert (1958) and Cockerham (1959) agreed that until experimentally proved otherwise, the absence of epistasis couldn't be assumed when dealing with quantitative traits. Many reports in castor, has shown non-allelic interactions for economically important traits (Pathak et al. 1988; Solanki et al. 2003; Golakia et al. 2004; Virani et al. 2013). Further, the type of nonallelic interactions varied in different crosses with different genetic backgrounds. The estimates of $m$, (d) and (h) parameters calculated on additive-dominance scale for characters showing epistasis interaction is biased to an unknown extent by effects not attributable to the additive and dominance action of genes (Mather and Jinks 1971). Estimates of additive (d) and dominance (h) components varied with cross to cross and character-to-character. The variable expression of gene effects in different crosses might be due to the genetic makeup of a particular cross and the effect of environmental condition on the expression of different traits. As in the present study, the importance of additive and dominance effects was also observed by Pathak et al. (1988), Gondaliya et al. (2001), Patel and Pathak (2010), Virani et al. (2013) and Pardshi et al. (2018) for seed yield and its components in castor. Preponderance of additive genetic variance for various traits revealed genetic improvement in yield would be easier through indirect selection of component traits. Since both additive and non-additive gene effects, as well as non-allelic interactions, were involved in the expression of yield and contributing traits in the majority of crosses, breeding methods involving high volume crossing, such as reciprocal recurrent selection (RRS), which exploits both additive and non-additive gene action, and biparental mating, can be used for genetic gain. Solanki et al. (2003) observed additive and all types of epistasis with high magnitude of dominance $x$ dominance (I) for plant height up to main raceme, number of nodes up to main raceme, total length of main raceme, effective length of main raceme and number of capsules on main

Page 5/33 
raceme in castor, while Golakiya et al. (2004) advocated presence of additive, dominance and epistasis gene effects for number of nodes up to main raceme, total length of main raceme, effective length of main raceme and seed yield per plant and Virani et al. (2013) for seed yield per plant and its components in castor. Singh and Yadava (1981) also reported partial and over dominance for days to flowering of raceme and seed yield per plant, respectively in castor.

Likewise, Singh (2012) in castor found trigenic ten-parameter model was adequate for various quantitative parameters along with non-significant $\chi^{2}{ }_{(3)}$ with two degree of freedom indicating major role of trigenic interaction for the inheritance of days to maturity, effective length of main raceme, 100 seed weight, shelling outturn and days to maturity. On the other hands, $\chi^{2}{ }_{(3)}$ with two degrees of freedom was also found to be significant for other quantitative traits showing the presence of even higher order epistasis and/or linkage. Besides, all the ten-parameters were also reported significant for effective length of main raceme and seed yield per plant. The opposite signs of either two or all the three gene effects viz., dominance [h], dominance $x$ dominance [l] and dominance $x$ dominance $x$ dominance $[z]$ suggests the presence of duplicate type of epistasis. In the present study, involvement of largely duplicate type of gene action was reported for the inheritance of seed yield and its component traits. Duplicate type of epistasis for seed yield per plant and its component traits in castor was reported earlier by Gondaliya et al. (2001), Golakiya et al. (2004), Singh (2012), Virani et al. (2013) and Sakhare et al. (2017). The presence of non-additive gene action further suggests that direct selection method may not be suitable for improvement of seed yield. Even though duplicate type of digenic interaction indicated greater genetic diversity for different traits the presence of duplicate epistasis would be detrimental for rapid progress, making it difficult to fix genotypes with increased level of character manifestation because the positive effect of one parameter would be cancelled out by the negative effect of another parameter (Sagar, 1990; Kumar et al. 2021). Because higher order interactions, in combination with additive and/or dominance gene activities, play a significant influence in the phenotypic expression of several traits, both population and heterosis breeding can be used to increase genetic gain

\section{Conclusion}

Overall, it could be concluded from the present study that oil content, seed yield per plant and its component traits were governed by varied level of additive, dominance and digenic and/or trigenic epistasis gene effects. When additive as well as non-additive effects are involved, a breeding scheme efficient in exploiting both types of gene effects should be employed. Reciprocal recurrent selection could be followed which would facilitate exploitation of both additive and non-additive gene effects simultaneously. Moreover, the duplicate type of gene action observed for almost all the characters studied in all the four crosses showed digenic/trigenic interaction. Under a situation of this type, it would be difficult for the plant breeders to get promising segregants better than parents involved through conventional breeding methods. Breeding procedures involving either multiple crosses or biparental crosses may be restored to get transgressive segregants, which would facilitate exploitation of both additive and non-additive gene effects simultaneously for genetic improvement of seed yield and its component traits in castor. The results of this study will help in identifying appropriate parents in crossing programme, selection in segregating generations, and in developing high yielding cultivars with elevated oil content. So, the earlier finding on gene effects in castor is mostly up to digenic interactions and this is first report on trigenic interactions or higher order interaction in castor so far.

\section{Declarations}

Acknowledgements: The first author wishes to gratitude Junagadh Agricultural University, Junagadh, Gujarat, India for Doctoral Research and allowing use of the necessary facilities and infrastructure to carry out the present research work. The pedigree information and seed materials provided by Main Oilseeds Research Station, JAU, Gujarat was highly acknowledge.

Conflict of interest: The authors declare that they have no conflict of interest.

\section{Compliance with ethical standards}

Conflict of interest The authors declare that they have no conflict of interest.

Human and animal rights: This article does not contain any studies with human or animal subjects

\section{References}

1. Anonymous (2017) Farmers may reduce castor acreage to have better price at harvest. http://www.jau.in/attachments\%5Cnaip\%5CPriceforecastJuly2013\%5Castor_PF_at_Kharif_Sowing_English_2016-17.pdf

2. Cavalli LL (1952) An analysis of linkage in quantitative inheritance in "Quantitative Inheritance". Reeve ECR, Waddington CH (eds), HMSO, London, pp 135-144

3. Cockerham CC (1959) Partitions of hereditary variances for various genetic models. Genetics 44:1141-1148

4. Gilbert NEG (1958) Diallel cross in plant breeding. Heredity 12:477-492

5. Golakia PR, Poshiya VK, Monpara BA (2015) Identification of superior donor parents for earliness through combining ability in castor (Ricinus communis L.). Int J Res PI Sci 5(3):26-31

6. Gondaliya AB, Dangaria CJ, Kavani RH, Golakia PR (2001) Genetic architecture for yield and its components in castor (Ricinus communis L.). J. Oilseeds Res 18(2):150-153

7. Hayman $\mathrm{Bl}(1958)$ The separation of epistatic from additive and dominance variation in generation means. Heredity 12(3):371-390

8. Hayman BI, Mather K (1955) The description of genetic interactions in continuous variation. Biometrics 11(1):69-82

9. Hill J (1966) Recurrent back crossing in the study of quantitative inheritance. Heredity 21(1):85-120 
10. Horner TW, Comstock RE, Obinson HF (1955) Non-allelic gene interactions and the interpretation of quantitative genetic data. North Carolina Agric. Tech. Bull 118

11. Kumar M, Patel M, Rani K (2021) Delineating genetic inheritance and nonallelic genic interactions for grain iron and zinc concentration, yield and its attributes by generation mean analysis in pearl millet [Pennisetum glaucum (L.) R. Br.]. Genet. Resour. Crop Evol. http://doi.org/10.1007/s10722-02101208-2

12. Mather K (1943) Polygenic inheritance and natural selection. Biol Rev 18:32-64

13. Mather K (1949) Biometrical Genetics. Dover Publication Ins, New York

14. Mather K, Jinks JL (1971) Biometrical Genetics: The study of continuous variation. Chapman and Hall, London, pp 65-82

15. Panse VG, Sukhatme PV (1978) Statistical methods for agri-cultural workers. ICAR Publication (2nd Edn.), New Delhi

16. Pardshi PP, Sakhare SB, Ingle KP, Khelurkar VC (2018) Genetic architecture studies of yield and its components in castor (Ricinus communis L.). Elec. J PI Breed 9(3):790-796

17. Patel DK, Patel A, Patel CJ, Jat AL (2021) Generation mean analysis for seed yield and wilt resistance in castor (Ricinus communis L.). Indian J Agric Res. DOI:10.18805/IJARe.A-5685

18. Patel PB, Pathak HC (2010) Genetic architecture for yield and its composition in castor (Ricinus communis L.). Int J Agril Sci 6(2):418-421

19. Pathak HC, Dixit SK, Patel PG (1988) Gene effects and heterosis in castor (Ricinus communis L.). Indian J Genet 49(1):125-129

20. R Development Core Team (2018) R: A language and envi-ronment for statistical computing. R Foundation for Sta-tistical Computing, Vienna, Austria.https://www.R-project.org

21. Sagar P (1990) Inheritance of plant height in pearl millet. Indian J Genet Plant Breed 50(3):233-239

22. Sakhare SB, Pardeshi P, Udasi RN, Nagdeve MB (2017) Genetic analysis of yield and its biometric traits in castor (Ricinus communis L.). Elec. J PI Breed 8(1):78-83

23. Sharma SN, Sain RS, Sharma RJ (2002) Genetic control of quantitative traits in durum wheat under normal and late-sowing environments. J Breed Genet 34(1):35-43

24. Shekhawat US, Bhardwaj RP, Prakash V (2000) Gene action for yield and its components in wheat (Triticum aestivum L.). Indian J Agril Res 34(3):176178

25. Singh H, Yadava TP (1981) Genetic analysis of days to flowering, maturity and yield in castor. Haryana Agric Univ J Res 11(1):54-59

26. Solanki SS, Joshi P, Gupta D, Deora VS (2003) Gene effects for yield contributing characters in castor (Ricinus communis L.) by generation mean analysis. J Oilseeds Res 20(2):217-219

27. Van der Veen JH (1959) Test of non-allelic interaction and linkage for quantitative characters in generations derived from two diploid pure lines. Genetica 30(1):201-232

28. Virani HP, Dhaduk HL, Mehta DR, Patel NB (2013) Genetic analysis in castor (Ricinus communis L.). AGRES-Int e-Journal 2(2):115-120

29. Weiss EA (2000) Oilseed Crops. Blackwell Science, Oxford, p 364

\section{Tables}

Table 1 List of genotypes used in the present study along with their pedigree, source and salient features

\begin{tabular}{|c|c|c|c|c|c|}
\hline $\begin{array}{l}\text { Sr. } \\
\text { No. }\end{array}$ & Name of genotypes & \multicolumn{2}{|l|}{ Pedigree } & Source & Salient features \\
\hline 1. & JP 104 & \multicolumn{2}{|c|}{$($ Geeta $\times$ JI 220) × Jl 244} & \multirow[t]{4}{*}{ Main Oilseeds Research Station, Junagadh Agricultural University, Junagadh } & G3SP \\
\hline 2. & Jl 433 & \multicolumn{2}{|c|}{ SKP $108 \times$ JI 295} & & M3SP \\
\hline 3. & Jl 437 & \multicolumn{2}{|c|}{ JP $89 \times$ SKI 291} & & M2SP \\
\hline 4. & JI 441 & \multicolumn{2}{|c|}{$\mathrm{JP} 96 \times \mathrm{JI} 338$} & & M3SP \\
\hline 5. & SKP 84 & \multicolumn{2}{|c|}{ SKP $1 \times$ VP 1} & Castor \& Mustard Research Station, S.D. Agricultural University, Dantiwada & M3SP \\
\hline & Stem colour & M & Mahos & any & Green \\
\hline & Bloom & 2 & Double & 3 & Triple \\
\hline & Capsule & $: \quad \mathrm{SP}$ & Spiny & & \\
\hline
\end{tabular}

Table 2 Analysis of variance between families and between progenies within family of twelve generations for different characters in castor 


\begin{tabular}{|c|c|c|c|c|c|c|c|c|c|c|c|c|}
\hline $\begin{array}{l}\text { Source of } \\
\text { variation }\end{array}$ & d.f. & $\begin{array}{l}\text { Days to } \\
\text { flowering } \\
\text { of } \\
\text { primary } \\
\text { raceme }\end{array}$ & $\begin{array}{l}\text { Days to } \\
\text { maturity } \\
\text { of } \\
\text { primary } \\
\text { raceme }\end{array}$ & $\begin{array}{l}\text { Plant } \\
\text { height up } \\
\text { to primary } \\
\text { raceme }\end{array}$ & $\begin{array}{l}\text { Number } \\
\text { of nodes } \\
\text { up to } \\
\text { primary } \\
\text { raceme }\end{array}$ & $\begin{array}{l}\text { Length of } \\
\text { primary } \\
\text { raceme }\end{array}$ & $\begin{array}{l}\text { Effective } \\
\text { length of } \\
\text { primary } \\
\text { raceme }\end{array}$ & $\begin{array}{l}\text { Number } \\
\text { of } \\
\text { effective } \\
\text { branches } \\
\text { per plant }\end{array}$ & $\begin{array}{l}\text { Number of } \\
\text { capsules } \\
\text { on primary } \\
\text { raceme }\end{array}$ & $\begin{array}{l}\text { Shelling } \\
\text { out turn }\end{array}$ & $\begin{array}{l}100 \\
\text { seed } \\
\text { weight }\end{array}$ & $\begin{array}{l}S \\
p\end{array}$ \\
\hline & \multicolumn{12}{|c|}{ Analysis of variance between families } \\
\hline Replications & 2 & 0.027 & 0.008 & 0.434 & 0.136 & 2.985 & 2.133 & 0.746 & 2.039 & 0.249 & $0.853^{\star *}$ & 2 \\
\hline Crosses & 3 & $13.500 * *$ & $38.215^{\star \star}$ & $14.676^{\star \star}$ & $1.628^{\star \star}$ & $33.148 * \star$ & $58.153^{\star \star}$ & $3.951^{\star \star}$ & $548.648^{\star *}$ & 29.461 ** & $2.117 * \star$ & 5 \\
\hline Error & 6 & 0.021 & 0.031 & 0.780 & 0.065 & 0.592 & 0.910 & 0.145 & 0.820 & 0.197 & 0.025 & 3 \\
\hline \multirow[t]{3}{*}{$\chi^{2}$} & 2 & NS & NS & NS & NS & $S$ & $S$ & $S$ & $\mathrm{~S}$ & $\mathrm{~S}$ & NS & $\mathrm{N}$ \\
\hline & \multicolumn{12}{|c|}{ Analysis of variance between progenies within family } \\
\hline & & \multicolumn{11}{|c|}{ JP 104 x JI 433} \\
\hline Replications & 2 & 0.020 & 0.243 & 1.383 & 0.198 & 0.675 & 0.445 & $7.379 * \star$ & 42.165 & 2.229 & $2.163^{\star}$ & 7 \\
\hline Generations & 11 & $4.598^{\star \star}$ & $8.140 \star \star$ & $118.253^{\star \star}$ & $2.390^{\star *}$ & $251.374^{\star \star}$ & $61.398 * \star$ & $14.129 * \star$ & $213.078^{\star \star}$ & $360.154 * \star$ & $8.135^{\star \star}$ & 4 \\
\hline \multirow[t]{2}{*}{ Error } & 22 & 0.151 & 0.181 & 4.152 & 0.231 & 0.765 & 1.524 & 1.135 & 22.248 & 1.682 & 0.433 & 2 \\
\hline & & \multicolumn{11}{|c|}{ SKP 84 x JI 433} \\
\hline Replications & 2 & 0.428 & 0.736 & 0.211 & 1.770 ** & $21.935^{\star}$ & $49.897 \star \star$ & 0.743 & 8,634 & 4.512 & $3.288^{\star \star}$ & 3 \\
\hline Generations & 11 & $19.166^{\star \star}$ & $14.515^{\star \star}$ & $103.851^{\star \star}$ & $3.200 * \star$ & $266.665^{\star \star}$ & $202.777^{\star \star \star}$ & $3.941^{\star \star}$ & $1061.537 * \star$ & 292.334 ** & $12.244^{\star \star}$ & 7 \\
\hline \multirow[t]{2}{*}{ Error } & 22 & 0.272 & 0.273 & 4.893 & 0.370 & 6.038 & 6.287 & 0.223 & 11.693 & 4.528 & 0.402 & 5 \\
\hline & & \multicolumn{11}{|c|}{ SKP 84 x JI 437} \\
\hline Replications & 2 & 0.306 & 0.050 & 4.147 & 0.253 & $25.141^{\star}$ & 0.889 & $3.593^{\star \star}$ & 0.310 & 2.510 & $2.435^{\star \star}$ & 1 \\
\hline Generations & 11 & $4.198^{\star \star}$ & 39.164 ** & $172.744 \star \star$ & $11.321^{\star \star}$ & $423.531^{\star \star}$ & 317.908 ** & $6.276^{\star \star}$ & $371.667 \star \star$ & 372.106 ** & $6.700 * *$ & 5 \\
\hline \multirow[t]{2}{*}{ Error } & 22 & 0.250 & 0.448 & 4.391 & 0.307 & 6.090 & 4.377 & 0.558 & 3.194 & 6.951 & 0.234 & 2 \\
\hline & & \multicolumn{11}{|c|}{ SKP 84 x JI 441} \\
\hline Replications & 2 & 0.311 & 0.189 & 27.530 & $1.720 *$ & 9.386 & 7.115 & 2.466 & 2.889 & 0.837 & $3.257^{\star}$ & 4 \\
\hline Generations & 11 & $4.643^{\star \star}$ & $16.215^{\star \star *}$ & $183.990 * *$ & $2.739 * \star$ & $319.292^{\star *}$ & $299.418^{\star \star}$ & 5.032 ** & $448.424^{\star \star}$ & $256.297 \star \star$ & 19.511 ** & 6 \\
\hline Error & 22 & 0.226 & 0.298 & 9.276 & 0.312 & 7.658 & 10.764 & 1.125 & 6.707 & 1.383 & 0.756 & 3 \\
\hline
\end{tabular}

*, ** Significant at 5 and 1 per cent level, respectively

$\chi 2=$ Chi-square for Bartlett's test of homogeneity of error variances, $\mathrm{S}=$ Significant and NS $=$ Non-significant

Table 3 Scaling tests and estimation of gene effects for days to flowering of primary raceme in four crosses of castor 


\begin{tabular}{|c|c|c|c|c|c|c|c|c|c|c|c|c|}
\hline \multirow{2}{*}{$\begin{array}{l}\text { Scaling tests / gene effects } \\
\text { A }\end{array}$} & \multicolumn{3}{|c|}{ JP 104 x JI 433} & \multicolumn{3}{|c|}{ SKP 84 x JI 433} & \multicolumn{3}{|c|}{ SKP 84 x JI 437} & \multicolumn{3}{|c|}{ SKP 84 x JI 441} \\
\hline & 1.18 & \pm & 0.98 & $-9.98 * \star$ & \pm & 1.04 & $-5.38 * \star$ & \pm & 0.99 & 0.24 & \pm & 1.31 \\
\hline B & $-1.87 \star \star$ & \pm & 0.68 & -1.91 & \pm & 1.09 & $-2.98^{\star \star}$ & \pm & 1.11 & $-3.82^{\star \star}$ & \pm & 0.97 \\
\hline C & $5.69 * \star$ & \pm & 1.11 & 0.33 & \pm & 1.91 & -1.01 & \pm & 1.49 & -3.45 & \pm & 2.14 \\
\hline D & $3.19 * *$ & \pm & 0.48 & $6.11^{\star \star}$ & \pm & 0.83 & $3.67^{\star \star *}$ & \pm & 0.84 & 0.06 & \pm & 0.98 \\
\hline $\mathrm{B}_{11}$ & $-12.44^{\star \star}$ & \pm & 2.29 & $15.40^{* \star}$ & \pm & 2.03 & $-3.36^{*}$ & \pm & 1.68 & -2.63 & \pm & 2.07 \\
\hline $\mathrm{B}_{12}$ & 0.43 & \pm & 1.11 & $12.67^{\star \star}$ & \pm & 2.38 & $9.44 * \star$ & \pm & 1.51 & 2.21 & \pm & 2.29 \\
\hline $\mathrm{B}_{21}$ & -2.39 & \pm & 1.43 & $26.57^{\star \star}$ & \pm & 2.03 & $6.83^{\star \star}$ & \pm & 1.76 & -1.37 & \pm & 2.16 \\
\hline$B_{22}$ & $-12.48^{\star \star}$ & \pm & 1.40 & 0.93 & \pm & 2.05 & $-3.89 * \star$ & \pm & 1.19 & $-10.00 * *$ & \pm & 2.05 \\
\hline $\mathrm{B}_{1 \mathrm{~S}}$ & $-15.88^{\star *}$ & \pm & 3.88 & $21.32^{\star \star}$ & \pm & 4.03 & 4.05 & \pm & 3.31 & $-11.37 \star \star *$ & \pm & 4.00 \\
\hline $\mathrm{B}_{2 \mathrm{~S}}$ & $-6.65^{\star}$ & \pm & 2.54 & $16.25^{\star \star}$ & \pm & 3.54 & $8.00 * \star$ & \pm & 2.36 & 1.59 & \pm & 3.59 \\
\hline$x$ & 0.71 & \pm & 0.56 & 0.14 & \pm & 0.70 & 0.79 & \pm & 0.52 & $2.74^{\star \star}$ & \pm & 0.68 \\
\hline Y & $5.74^{\star \star}$ & \pm & 0.64 & $5.73^{\star \star}$ & \pm & 0.92 & $5.88^{* *}$ & \pm & 0.67 & $3.37 * \star$ & \pm & 0.91 \\
\hline \multicolumn{13}{|c|}{ Three parameter model (Cavalli) } \\
\hline $\mathrm{m}$ & $59.10 * *$ & \pm & 0.14 & $61.09 * *$ & \pm & 0.19 & $62.00 * *$ & \pm & 0.13 & $62.75^{\star \star}$ & \pm & 0.19 \\
\hline (d) & $0.87^{\star \star}$ & \pm & 0.14 & $1.83^{\star *}$ & \pm & 0.17 & $1.11^{\star \star}$ & \pm & 0.12 & 0.12 & \pm & 0.17 \\
\hline (h) & $-1.56^{\star \star}$ & \pm & 0.25 & -0.31 & \pm & 0.37 & $-2.07 * \star$ & \pm & 0.29 & $1.08^{\star \star}$ & \pm & 0.39 \\
\hline$\chi^{2}{ }_{(1)}(9 \mathrm{df})$ & $202.84^{\star \star}$ & & & $347.54 * \star$ & & & 144.61 ** & & & $170.46^{\star *}$ & & \\
\hline \multicolumn{13}{|c|}{ Six parameter model (Hayman) } \\
\hline $\mathrm{m}$ & $58.70^{* \star}$ & \pm & 0.13 & $64.13^{\star \star}$ & \pm & 0.32 & $61.54^{\star *}$ & \pm & 0.27 & $62.38^{\star \star}$ & \pm & 0.39 \\
\hline (d) & $1.55^{\star \star}$ & \pm & 0.40 & -0.46 & \pm & 0.51 & -0.40 & \pm & 0.63 & $2.00 \star \star$ & \pm & 0.57 \\
\hline (h) & $-5.08^{\star \star}$ & \pm & 1.08 & $-7.38 * *$ & \pm & 1.80 & $-6.54^{\star \star}$ & \pm & 1.75 & 2.97 & \pm & 2.09 \\
\hline (i) & $-6.38 * \star$ & \pm & 0.96 & $-12.22^{\star \star}$ & \pm & 1.66 & $-7.34^{\star \star}$ & \pm & 1.68 & -0.14 & \pm & 1.96 \\
\hline (j) & $1.52^{\star \star}$ & \pm & 0.56 & $-4.03 * \star$ & \pm & 0.62 & -1.20 & \pm & 0.68 & $2.03^{\star *}$ & \pm & 0.69 \\
\hline (l) & $7.07 \star \star$ & \pm & 1.97 & $24.11^{\star *}$ & \pm & 2.81 & $15.69 * \star$ & \pm & 2.93 & 3.70 & \pm & 3.15 \\
\hline \multicolumn{13}{|c|}{ Digenic and trigenic interactions (Hill) } \\
\hline $\mathrm{m}$ & $58.09 * *$ & \pm & 0.54 & $62.52^{\star \star}$ & \pm & 0.76 & $60.58 * \star$ & \pm & 0.66 & $61.54^{\star \star}$ & \pm & 0.71 \\
\hline (d) & 0.36 & \pm & 0.25 & $04.22^{\star *}$ & \pm & 0.28 & $1.25^{\star \star}$ & \pm & 0.21 & $-1.26^{\star *}$ & \pm & 0.30 \\
\hline (h) & 2.50 & \pm & 1.69 & -6.51 ** & \pm & 2.32 & 0.84 & \pm & 1.96 & 2.78 & \pm & 2.22 \\
\hline (i) & 0.41 & \pm & 0.52 & -1.31 & \pm & 0.75 & $1.68^{\star \star}$ & \pm & 0.64 & $1.90 \star \star$ & \pm & 0.71 \\
\hline (j) & $1.68^{\star}$ & \pm & 0.74 & -10.59 ** & \pm & 0.94 & -0.55 & \pm & 0.80 & $5.24 * *$ & \pm & 0.98 \\
\hline (I) & $-3.52^{\star \star}$ & \pm & 1.35 & $06.88^{* *}$ & \pm & 1.94 & -1.42 & \pm & 1.57 & -0.16 & \pm & 1.91 \\
\hline$\chi^{2}{ }_{(2)}(6 \mathrm{df})$ & 191.90 ** & & & $202.19 * *$ & & & 136.07 ** & & & $132.28^{* *}$ & & \\
\hline $\mathrm{m}$ & $57.61^{\star \star}$ & \pm & 0.69 & 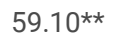 & \pm & 1.12 & $59.96 * \star$ & \pm & 0.86 & $65.68^{* \star}$ & \pm & 1.02 \\
\hline (d) & $3.77^{\star \star}$ & \pm & 1.05 & $7.68^{\star \star}$ & \pm & 1.56 & $3.00 *$ & \pm & 1.18 & $7.11^{\star \star}$ & \pm & 1.36 \\
\hline (h) & $4.85^{\star}$ & \pm & 2.40 & $16.41^{\star \star}$ & \pm & 4.34 & $6.88^{\star}$ & \pm & 3.42 & $-13.32^{\star \star}$ & \pm & 4.37 \\
\hline (i) & -0.01 & \pm & 0.80 & 2.17 & \pm & 1.20 & 1.68 & \pm & 0.91 & $-3.49 * \star$ & \pm & 1.13 \\
\hline (j) & $-8.64^{\star \star}$ & \pm & 2.98 & $-12.99 * \star$ & \pm & 4.04 & -5.62 & \pm & 2.97 & $-20.42^{\star \star}$ & \pm & 3.67 \\
\hline (I) & $-6.52^{\star \star}$ & \pm & 2.03 & $-17.43^{\star \star}$ & \pm & 3.90 & $-9.25^{\star \star}$ & \pm & 3.08 & $13.08^{\star \star}$ & \pm & 4.09 \\
\hline$(w)$ & $-3.23^{\star \star}$ & \pm & 1.04 & -4.18 *夫 & \pm & 1.55 & -1.99 & \pm & 1.17 & $-7.34^{\star \star}$ & \pm & 1.35 \\
\hline$(x)$ & -1.64 & \pm & 2.30 & $-35.08^{\star \star}$ & \pm & 4.17 & $-12.68 \star \star$ & \pm & 3.47 & 13.04 ** & \pm & 4.79 \\
\hline
\end{tabular}

Page 9/33 


\begin{tabular}{|c|c|c|c|c|c|c|c|c|c|c|c|c|}
\hline (y) & 8.28 ** & \pm & 2.79 & -6.34 & \pm & 3.71 & 3.23 & \pm & 2.77 & $25.02^{\star \star}$ & \pm & 3.54 \\
\hline (z) & $2.59 \star \star$ & \pm & 0.37 & $7.47^{\star \star *}$ & \pm & 0.68 & 4.91 ** & \pm & 0.53 & $0.51^{\star \star}$ & \pm & 0.72 \\
\hline$\chi^{2}{ }_{(3)}(2 \mathrm{df})$ & $99.90 * *$ & & & $37.89 * \star$ & & & $17.50 * \star$ & & & 49.94 ** & & \\
\hline
\end{tabular}

*, ** Significant at 5 and $1 \%$ levels, respectively

Table 4 Scaling tests and estimation of gene effects for days to maturity of primary raceme in four crosses of castor 


\begin{tabular}{|c|c|c|c|c|c|c|c|c|c|c|c|c|}
\hline \multirow{2}{*}{$\begin{array}{l}\text { Scaling tests /gene effects } \\
\text { A }\end{array}$} & \multicolumn{3}{|c|}{ JP 104 x JI 433} & \multicolumn{3}{|c|}{ SKP 84 x JI 433} & \multicolumn{3}{|c|}{ SKP 84 x JI 437} & \multicolumn{3}{|c|}{ SKP 84 x JI 441} \\
\hline & $-1.33^{*}$ & \pm & 0.62 & 1.20 & \pm & 1.03 & 1.38 & \pm & 0.81 & $5.04^{\star \star}$ & \pm & 0.93 \\
\hline B & -1.33 & \pm & 0.80 & $7.53^{\star \star}$ & \pm & 1.05 & 13.91 ** & \pm & 0.88 & $3.11^{\star}$ & \pm & 1.47 \\
\hline C & $5.07 \star \star$ & \pm & 1.58 & $11.75^{\star \star}$ & \pm & 2.14 & $12.21^{\star \star}$ & \pm & 1.84 & $3.53^{\star}$ & \pm & 1.67 \\
\hline D & $3.87 * \star$ & \pm & 0.68 & 1.51 & \pm & 0.80 & $-1.54^{\star}$ & \pm & 0.75 & $-2.31 *$ & \pm & 0.94 \\
\hline $\mathrm{B}_{11}$ & $-14.08^{\star \star}$ & \pm & 1.43 & $-4.16^{\star}$ & \pm & 1.67 & $-4.29 \star \star$ & \pm & 1.22 & $-8.09 * \star$ & \pm & 1.45 \\
\hline $\mathrm{B}_{12}$ & 0.91 & \pm & 1.63 & -1.99 & \pm & 2.86 & -2.96 & \pm & 2.60 & 1.33 & \pm & 2.24 \\
\hline $\mathrm{B}_{21}$ & $-5.97 \star \star$ & \pm & 1.76 & $-5.07 \star$ & \pm & 2.55 & $11.49 * \star$ & \pm & 2.69 & -0.01 & \pm & 2.03 \\
\hline $\mathrm{B}_{22}$ & $-9.33^{\star \star}$ & \pm & 1.45 & $-14.44^{\star \star}$ & \pm & 1.84 & $-27.17 \star \star$ & \pm & 2.24 & $-3.31 *$ & \pm & 1.27 \\
\hline $\mathrm{B}_{1 \mathrm{~S}}$ & $-14.83^{\star \star}$ & \pm & 2.72 & $-10.36^{\star \star}$ & \pm & 3.47 & $-18.56^{\star \star}$ & \pm & 2.67 & $-9.93^{\star *}$ & \pm & 2.69 \\
\hline $\mathrm{B}_{2 \mathrm{~S}}$ & $-17.60^{\star \star}$ & \pm & 2.45 & -5.61 & \pm & 3.29 & $-32.32^{\star \star}$ & \pm & 3.54 & $-8.07 \star \star$ & \pm & 2.76 \\
\hline$x$ & 0.53 & \pm & 0.53 & $3.34^{\star \star}$ & \pm & 0.67 & $2.11^{\star}$ & \pm & 0.87 & -0.86 & \pm & 0.57 \\
\hline Y & $4.59 * \star$ & \pm & 0.69 & $2.89 \star \star$ & \pm & 1.02 & $10.00 \star \star$ & \pm & 1.04 & $3.18^{\star *}$ & \pm & 0.80 \\
\hline \multicolumn{13}{|c|}{ Three parameter model (Cavalli) } \\
\hline $\mathrm{m}$ & $114.24^{\star \star}$ & \pm & 0.13 & $120.10 * \star$ & \pm & 0.17 & $117.72^{\star \star}$ & \pm & 0.17 & $120.36 * \star$ & \pm & 0.14 \\
\hline (d) & $-2.30 * \star$ & \pm & 0.12 & $2.54^{\star \star}$ & \pm & 0.15 & $3.81^{* \star}$ & \pm & 0.14 & $3.13^{\star \star}$ & \pm & 0.12 \\
\hline (h) & $-0.85^{\star \star}$ & \pm & 0.29 & $2.94^{\star \star}$ & \pm & 0.38 & $3.21 \star \star$ & \pm & 0.41 & $3.29 * \star$ & \pm & 0.34 \\
\hline$\chi^{2}{ }_{(1)}(9 \mathrm{df})$ & $319.98^{* *}$ & & & $149.70 * *$ & & & $487.68^{\star \star}$ & & & $76.54 * \star$ & & \\
\hline \multicolumn{13}{|c|}{ Six parameter model (Hayman) } \\
\hline $\mathrm{m}$ & $114.33^{\star \star}$ & \pm & 0.30 & $122.92^{\star \star}$ & \pm & 0.34 & $119.78^{\star \star}$ & \pm & 0.33 & $122.06 * \star$ & \pm & 0.28 \\
\hline (d) & $-1.86^{\star \star}$ & \pm & 0.32 & 0.20 & \pm & 0.41 & 0.35 & \pm & 0.35 & $3.60 * \star$ & \pm & 0.74 \\
\hline (h) & $-6.13^{\star \star}$ & \pm & 1.46 & -0.98 & \pm & 1.81 & $7.07 \star \star$ & \pm & 1.63 & $8.65^{\star \star}$ & \pm & 1.97 \\
\hline (i) & $-7.73^{\star \star}$ & \pm & 1.37 & -3.01 & \pm & 1.61 & $3.07 *$ & \pm & 1.51 & $4.62^{\star}$ & \pm & 1.87 \\
\hline (j) & 0.90 & \pm & 0.39 & $-3.16^{\star \star}$ & \pm & 0.49 & $-6.26^{\star \star}$ & \pm & 0.44 & 0.96 & \pm & 0.77 \\
\hline (I) & $10.40 * *$ & \pm & 2.04 & $-5.72^{\star}$ & \pm & 2.71 & $-18.36^{\star \star}$ & \pm & 2.32 & $-12.77^{\star \star \star}$ & \pm & 3.40 \\
\hline \multicolumn{13}{|c|}{ Digenic and trigenic interactions (Hill) } \\
\hline $\mathrm{m}$ & $116.90 * *$ & \pm & 0.54 & 116.70 ** & \pm & 0.76 & $115.45^{\star *}$ & \pm & 0.65 & $118.50 * \star$ & \pm & 0.63 \\
\hline (d) & $-2.22^{\star \star}$ & \pm & 0.20 & $3.26^{\star \star}$ & \pm & 0.23 & $6.24^{\star \star}$ & \pm & 0.23 & $2.75^{\star \star}$ & \pm & 0.20 \\
\hline (h) & $-6.11 * \star$ & \pm & 1.59 & $17.01^{\star \star}$ & \pm & 2.21 & $19.20^{\star \star}$ & \pm & 1.87 & $12.30 * \star$ & \pm & 1.92 \\
\hline (i) & $-3.32 \star \star$ & \pm & 0.54 & $2.30^{\star \star}$ & \pm & 0.75 & -0.24 & \pm & 0.65 & 0.89 & \pm & 0.61 \\
\hline (j) & 0.35 & \pm & 0.65 & $-3.66^{\star \star}$ & \pm & 0.82 & $-11.43^{\star \star}$ & \pm & 0.81 & $1.91^{*}$ & \pm & 0.82 \\
\hline (I) & 2.43 & \pm & 1.34 & $-13.46^{\star \star}$ & \pm & 1.86 & $-19.06^{\star \star}$ & \pm & 1.58 & $-9.32^{\star \star}$ & \pm & 1.59 \\
\hline$\chi^{2}{ }_{(2)}(6 \mathrm{df})$ & $276.15^{\star \star}$ & & & $69.37 \star \star$ & & & $111.96^{* \star}$ & & & $26.97 * \star$ & & \\
\hline $\mathrm{m}$ & $117.00 * \star$ & \pm & 0.81 & $114.90 * \star$ & \pm & 1.07 & $117.42^{\star \star}$ & \pm & 0.99 & $120.12^{\star \star}$ & \pm & 0.88 \\
\hline (d) & $-2.34 \star \star$ & \pm & 1.07 & $10.49 \star \star$ & \pm & 1.41 & $12.99 \star \star$ & \pm & 1.40 & 0.71 & \pm & 1.10 \\
\hline (h) & $-4.37 \star$ & \pm & 3.43 & $28.25^{\star \star}$ & \pm & 4.34 & $9.66^{\star}$ & \pm & 4.00 & 5.10 & \pm & 3.57 \\
\hline (i) & -4.18 & \pm & 0.86 & $4.08^{\star \star}$ & \pm & 1.12 & $-2.91 * \star$ & \pm & 1.04 & -1.05 & \pm & 0.92 \\
\hline (j) & $-1.17^{\star \star \star}$ & \pm & 2.85 & $-23.58 * \star$ & \pm & 3.60 & $-32.47^{\star \star}$ & \pm & 3.80 & $8.04^{\star \star}$ & \pm & 2.74 \\
\hline (I) & $-0.79 \star \star$ & \pm & 3.18 & $-25.30 * \star$ & \pm & 4.00 & -11.96 ** & \pm & 3.65 & -3.21 & \pm & 3.25 \\
\hline$(w)$ & $0.59 * \star$ & \pm & 1.06 & $-7.04 \star \star$ & \pm & 1.41 & $-6.72^{\star \star}$ & \pm & 1.39 & 1.87 & \pm & 1.10 \\
\hline$(x)$ & -4.93 & \pm & 3.49 & $-16.26^{\star \star}$ & \pm & 4.17 & $9.20 *$ & \pm & 3.99 & 6.17 & \pm & 3.52 \\
\hline
\end{tabular}




\begin{tabular}{|c|c|c|c|c|c|c|c|c|c|c|c|c|}
\hline (y) & $3.23^{\star \star}$ & \pm & 2.87 & $16.88^{\star \star}$ & \pm & 3.50 & 19.90 ** & \pm & 4.13 & -5.43 & \pm & 2.82 \\
\hline (z) & 3.76 ** & \pm & 0.55 & $2.95^{\star \star}$ & \pm & 0.69 & $2.67 \star \star$ & \pm & 0.64 & 0.79 & \pm & 0.59 \\
\hline$\chi^{2}{ }_{(3)}(2 \mathrm{df})$ & $189.22^{\star \star}$ & & & $11.89 * \star$ & & & $34.95^{\star \star}$ & & & $8.60 *$ & & \\
\hline
\end{tabular}

*, ** Significant at 5 and $1 \%$ levels, respectively

Table 5 Scaling tests and estimation of gene effects for plant height up to primary raceme in four crosses of castor 


\begin{tabular}{|c|c|c|c|c|c|c|c|c|c|c|c|c|}
\hline \multirow{2}{*}{$\begin{array}{l}\text { Scaling tests /gene effects } \\
\text { A }\end{array}$} & \multicolumn{3}{|c|}{ JP 104 x JI 433} & \multicolumn{3}{|c|}{ SKP 84 x JI 433} & \multicolumn{3}{|c|}{ SKP 84 x JI 437} & \multicolumn{3}{|c|}{ SKP 84 x JI 441} \\
\hline & $-32.40 \star \star$ & \pm & 3.89 & 5.03 & \pm & 3.79 & 4.26 & \pm & 4.76 & -12.20 & \pm & 6.15 \\
\hline B & $-16.54^{\star *}$ & \pm & 4.70 & $-24.23^{\star \star}$ & \pm & 4.69 & 3.10 & \pm & 5.95 & 5.02 & \pm & 5.01 \\
\hline C & $-50.13^{\star \star}$ & \pm & 6.54 & -10.51 & \pm & 7.22 & $-35.32 * \star$ & \pm & 9.61 & 6.71 & \pm & 9.31 \\
\hline D & -0.60 & \pm & 3.75 & 4.35 & \pm & 3.81 & $-21.34^{\star \star}$ & \pm & 3.64 & 6.95 & \pm & 3.83 \\
\hline$B_{11}$ & $12.67 *$ & \pm & 6.26 & 17.11 & \pm & 9.49 & 15.11 & \pm & 9.44 & $-46.15^{\star \star}$ & \pm & 11.79 \\
\hline$B_{12}$ & $37.97 * *$ & \pm & 6.65 & $46.64^{\star *}$ & \pm & 6.01 & $-73.53^{\star *}$ & \pm & 10.75 & $-38.06 * \star$ & \pm & 9.93 \\
\hline $\mathrm{B}_{21}$ & 6.40 & \pm & 4.43 & $25.39 \star \star$ & \pm & 7.77 & $-29.42^{\star}$ & \pm & 11.22 & 20.81 & \pm & 11.41 \\
\hline$B_{22}$ & $56.49 * \star$ & \pm & 10.86 & $26.57^{* *}$ & \pm & 8.03 & 26.11 & \pm & 14.32 & 74.30 & \pm & 10.18 \\
\hline $\mathrm{B}_{1 \mathrm{~S}}$ & $81.86^{\star \star}$ & \pm & 15.59 & $-64.39 * *$ & \pm & 16.50 & $81.54^{\star \star}$ & \pm & 17.92 & -12.27 & \pm & 21.97 \\
\hline $\mathrm{B}_{2 \mathrm{~S}}$ & 32.28 & \pm & 19.13 & 16.59 & \pm & 15.75 & $-58.97 *$ & \pm & 24.94 & $-44.88^{\star \star}$ & \pm & 19.15 \\
\hline $\mathrm{x}$ & -3.06 & \pm & 3.05 & 2.95 & \pm & 3.13 & $-13.78^{\star *}$ & \pm & 3.76 & $-44.83^{\star *}$ & \pm & 3.37 \\
\hline Y & $-6.20 *$ & \pm & 3.12 & $7.09 *$ & \pm & 3.32 & $-36.04 * \star$ & \pm & 4.76 & $-11.35^{\star}$ & \pm & 4.44 \\
\hline \multicolumn{13}{|c|}{ Three parameter model (Cavalli) } \\
\hline $\mathrm{m}$ & $56.48 * \star$ & \pm & 0.74 & $69.00 \star \star$ & \pm & 0.78 & $61.41 * \star$ & \pm & 1.01 & $63.75^{\star \star}$ & \pm & 0.89 \\
\hline (d) & $5.99 * *$ & \pm & 0.77 & $6.19 * \star$ & \pm & 0.76 & $-1.85^{\star}$ & \pm & 0.90 & $7.62^{\star \star}$ & \pm & 0.78 \\
\hline (h) & $14.10 \star \star$ & \pm & 1.05 & $-3.97 \star \star$ & \pm & 1.39 & $4.36^{\star}$ & \pm & 2.00 & $3.73^{\star}$ & \pm & 1.81 \\
\hline$\chi^{2}{ }_{(1)}(9 \mathrm{df})$ & $161.52^{\star \star}$ & & & 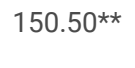 & & & $238.01^{\star \star}$ & & & $335.81^{\star \star}$ & & \\
\hline \multicolumn{13}{|c|}{ Six parameter model (Hayman) } \\
\hline $\mathrm{m}$ & $56.42^{\star \star}$ & \pm & 1.38 & $67.23^{\star \star}$ & \pm & 1.49 & $51.89 * \star$ & \pm & 1.48 & $64.48 * \star$ & \pm & 1.43 \\
\hline (d) & $-6.51 *$ & \pm & 2.54 & $15.47^{\star \star *}$ & \pm & 2.36 & 2.15 & \pm & 2.12 & $-8.75^{\star \star}$ & \pm & 2.54 \\
\hline (h) & 8.53 & \pm & 7.71 & -7.51 & \pm & 7.88 & $24.73^{\star \star}$ & \pm & 8.21 & $-17.18^{\star}$ & \pm & 8.50 \\
\hline (i) & 1.19 & \pm & 7.51 & -8.69 & \pm & 7.62 & $42.67 \star \star$ & \pm & 7.28 & -13.89 & \pm & 7.67 \\
\hline (j) & $-7.93^{\star *}$ & \pm & 3.01 & $14.63^{\star \star}$ & \pm & 2.91 & 0.58 & \pm & 3.20 & $-8.60 *$ & \pm & 3.40 \\
\hline$(\mathrm{l})$ & $47.74^{\star \star}$ & \pm & 12.09 & $27.90^{*}$ & \pm & 11.91 & $-50.03^{\star \star}$ & \pm & 12.82 & 21.07 & \pm & 13.80 \\
\hline \multicolumn{13}{|c|}{ Digenic and trigenic interactions (Hill) } \\
\hline $\mathrm{m}$ & $64.11 \star *$ & \pm & 3.66 & $95.15^{\star \star}$ & \pm & 3.22 & $53.08 * \star$ & \pm & 3.76 & $75.86^{\star \star}$ & \pm & 3.71 \\
\hline (d) & 1.70 & \pm & 1.26 & -0.38 & \pm & 1.33 & 3.26 & \pm & 1.68 & $18.72^{\star \star}$ & \pm & 1.55 \\
\hline (h) & $-28.77^{\star \star}$ & \pm & 9.58 & $-78.89 \star \star$ & \pm & 8.98 & 12.68 & \pm & 11.40 & $-35.56^{\star \star}$ & \pm & 11.54 \\
\hline (i) & 0.63 & \pm & 3.73 & $-25.09 * *$ & \pm & 3.31 & $13.17^{* *}$ & \pm & 3.74 & $-8.93^{*}$ & \pm & 3.48 \\
\hline (j) & $9.53^{\star}$ & \pm & 4.13 & $26.49 * *$ & \pm & 4.31 & $-19.96 * \star$ & \pm & 4.96 & $-41.23^{\star \star}$ & \pm & 5.03 \\
\hline (I) & $37.81^{\star \star}$ & \pm & 6.38 & $52.88^{\star \star}$ & \pm & 6.55 & 2.86 & \pm & 9.58 & $28.35^{\star \star}$ & \pm & 9.66 \\
\hline$\chi^{2}{ }_{(2)}(6 \mathrm{df})$ & $77.84^{\star \star}$ & & & $41.13^{\star \star}$ & & & 193.20 ** & & & $263.63^{\star \star}$ & & \\
\hline $\mathrm{m}$ & $64.97 \star \star$ & \pm & 5.12 & $101.05^{\star \star}$ & \pm & 4.36 & $69.67 * \star$ & \pm & 5.11 & $73.84^{\star \star *}$ & \pm & 4.89 \\
\hline (d) & $-31.12^{\star \star}$ & \pm & 7.67 & $18.59 * \star$ & \pm & 6.24 & $-57.29 * \star$ & \pm & 7.22 & $-55.06 * \star$ & \pm & 6.76 \\
\hline (h) & $-39.14^{\star}$ & \pm & 18.77 & $-109.80^{* *}$ & \pm & 17.36 & $-71.24 \star \star$ & \pm & 19.76 & -22.71 & \pm & 18.97 \\
\hline (i) & 0.42 & \pm & 5.49 & $-33.67 \star \star$ & \pm & 4.76 & 2.43 & \pm & 5.90 & -7.63 & \pm & 5.51 \\
\hline (j) & $78.17 * \star$ & \pm & 19.26 & -20.99 & \pm & 16.45 & $135.86^{\star \star}$ & \pm & 19.88 & $209.15^{\star \star}$ & \pm & 17.91 \\
\hline (I) & $52.00 * \star$ & \pm & 16.28 & $80.77^{\star \star *}$ & \pm & 15.63 & $87.00 * \star$ & \pm & 17.65 & 11.70 & \pm & 16.96 \\
\hline$(w)$ & $33.17 \star \star$ & \pm & 7.63 & $-19.21^{\star \star}$ & \pm & 6.21 & $57.42^{\star \star}$ & \pm & 7.14 & 57.06 ** & \pm & 6.66 \\
\hline$(x)$ & 12.13 & \pm & 18.60 & $43.30 *$ & \pm & 18.22 & $100.90 * \star$ & \pm & 19.60 & -1.33 & \pm & 19.16 \\
\hline
\end{tabular}




\begin{tabular}{|c|c|c|c|c|c|c|c|c|c|c|c|c|}
\hline (y) & $-34.36 *$ & \pm & 17.07 & $36.38^{*}$ & \pm & 16.20 & $-105.53^{\star *}$ & \pm & 19.54 & $-253.92^{\star *}$ & \pm & 16.99 \\
\hline (z) & -5.11 & \pm & 2.66 & -2.07 & \pm & 2.72 & $-30.52^{\star \star}$ & \pm & 3.06 & -0.80 & \pm & 2.98 \\
\hline$\chi_{(3)}^{2}(2 \mathrm{df})$ & $49.36^{\star \star}$ & & & $21.64^{\star \star}$ & & & $16.08^{\star \star}$ & & & 20.80 ** & & \\
\hline
\end{tabular}

*, ** Significant at 5 and $1 \%$ levels, respectively

Table 6 Scaling tests and estimation of gene effects for number of nodes up to primary raceme in four crosses of castor 


\begin{tabular}{|c|c|c|c|c|c|c|c|c|c|c|c|c|}
\hline \multirow{2}{*}{$\begin{array}{l}\text { Scaling tests /gene effects } \\
\text { A }\end{array}$} & \multicolumn{3}{|c|}{ JP 104 x JI 433} & \multicolumn{3}{|c|}{ SKP 84 x JI 433} & \multicolumn{3}{|c|}{ SKP 84 x JI 437} & \multicolumn{3}{|c|}{ SKP 84 x JI 441} \\
\hline & -1.58 & \pm & 0.96 & $4.02^{\star \star}$ & \pm & 1.12 & $7.58^{\star \star}$ & \pm & 1.74 & $3.49 * \star$ & \pm & 1.03 \\
\hline B & $-3.07 \star \star$ & \pm & 0.88 & 0.11 & \pm & 0.94 & -0.13 & \pm & 1.14 & $4.22^{\star \star}$ & \pm & 1.12 \\
\hline C & -0.68 & \pm & 1.58 & 2.43 & \pm & 2.11 & -1.51 & \pm & 1.76 & 1.48 & \pm & 1.71 \\
\hline D & $1.98^{\star}$ & \pm & 0.79 & -0.85 & \pm & 0.87 & $-4.48 * \star$ & \pm & 1.18 & $-3.12^{\star \star}$ & \pm & 0.82 \\
\hline $\mathrm{B}_{11}$ & -3.16 & \pm & 2.12 & $-10.23^{\star \star}$ & \pm & 2.67 & $8.41^{\star \star}$ & \pm & 1.85 & $-6.07 * \star$ & \pm & 2.02 \\
\hline $\mathrm{B}_{12}$ & $4.56^{\star *}$ & \pm & 1.51 & -4.23 & \pm & 2.21 & $12.05^{\star \star}$ & \pm & 1.91 & -0.56 & \pm & 2.34 \\
\hline $\mathrm{B}_{21}$ & $-3.67 \star$ & \pm & 1.69 & $-11.96 * \star$ & \pm & 2.24 & 1.88 & \pm & 1.90 & 2.01 & \pm & 1.94 \\
\hline $\mathrm{B}_{22}$ & $6.64^{\star \star}$ & \pm & 1.32 & $-4.95^{\star \star}$ & \pm & 1.24 & $-8.80 * \star$ & \pm & 1.66 & -1.63 & \pm & 2.05 \\
\hline $\mathrm{B}_{1 \mathrm{~s}}$ & $14.44^{\star \star}$ & \pm & 3.61 & -8.61 & \pm & 5.01 & 2.09 & \pm & 3.95 & $-13.69 * *$ & \pm & 3.59 \\
\hline $\mathrm{B}_{2 \mathrm{~S}}$ & 6.71 & \pm & 3.59 & -4.35 & \pm & 2.86 & $-8.73^{\star \star}$ & \pm & 2.85 & -0.20 & \pm & 4.30 \\
\hline$x$ & -0.39 & \pm & 0.61 & 0.61 & \pm & 0.66 & $6.85^{\star \star}$ & \pm & 0.68 & $-1.75^{\star}$ & \pm & 0.77 \\
\hline Y & -0.65 & \pm & 0.72 & -0.25 & \pm & 0.92 & $3.58^{\star \star}$ & \pm & 0.81 & $2.29 *$ & \pm & 0.90 \\
\hline \multicolumn{13}{|c|}{ Three parameter model (Cavalli) } \\
\hline $\mathrm{m}$ & $15.39 \star \star$ & \pm & 0.17 & $16.03^{\star \star}$ & \pm & 0.18 & $15.09 * \star$ & \pm & 0.18 & $16.78^{\star \star}$ & \pm & 0.20 \\
\hline (d) & -0.22 & \pm & 0.16 & $-0.33^{\star}$ & \pm & 0.16 & -0.23 & \pm & 0.17 & 0.03 & \pm & 0.18 \\
\hline (h) & -0.40 & \pm & 0.33 & -0.07 & \pm & 0.36 & $2.08^{\star \star}$ & \pm & 0.37 & 0.58 & \pm & 0.41 \\
\hline$\chi^{2}{ }_{(1)}(9 \mathrm{df})$ & $95.76^{\star \star}$ & & & $67.39 * \star$ & & & $168.75^{\star \star}$ & & & $52.16^{\star \star}$ & & \\
\hline \multicolumn{13}{|c|}{ Six parameter model (Hayman) } \\
\hline $\mathrm{m}$ & $15.61^{\star \star}$ & \pm & 0.30 & $15.10 \star \star$ & \pm & 0.37 & $16.17 * \star$ & \pm & 0.35 & $16.85^{\star \star}$ & \pm & 0.30 \\
\hline (d) & -0.08 & \pm & 0.50 & 0.62 & \pm & 0.43 & $4.82^{\star \star}$ & \pm & 0.95 & -0.86 & \pm & 0.57 \\
\hline (h) & $-4.86^{\star \star}$ & \pm & 1.65 & 0.70 & \pm & 1.89 & $12.51 \star \star$ & \pm & 2.42 & $7.93^{\star \star}$ & \pm & 1.76 \\
\hline (i) & $-3.96^{\star}$ & \pm & 1.57 & 1.70 & \pm & 1.73 & $8.95^{\star \star}$ & \pm & 2.36 & $6.23^{\star \star}$ & \pm & 1.66 \\
\hline (j) & 0.74 & \pm & 0.59 & $1.95^{\star \star}$ & \pm & 0.58 & $3.85^{\star \star}$ & \pm & 0.99 & -0.36 & \pm & 0.68 \\
\hline (l) & $8.61^{\star \star}$ & \pm & 2.55 & $-5.84^{\star}$ & \pm & 2.72 & $-16.39 \star \star$ & \pm & 4.19 & $13.94 \star \star$ & \pm & 2.85 \\
\hline \multicolumn{13}{|c|}{ Digenic and trigenic interactions (Hill) } \\
\hline $\mathrm{m}$ & $14.24^{\star \star}$ & \pm & 0.77 & 12.94 ** & \pm & 0.80 & 16.91 ** & \pm & 0.82 & $15.41^{\star \star}$ & \pm & 0.83 \\
\hline (d) & $-0.99 * \star$ & \pm & 0.26 & $-1.28 * \star$ & \pm & 0.29 & -0.39 & \pm & 0.26 & 0.27 & \pm & 0.31 \\
\hline (h) & 0.25 & \pm & 2.14 & $9.51^{\star \star}$ & \pm & 2.25 & -1.90 & \pm & 2.44 & $6.83^{\star \star}$ & \pm & 2.43 \\
\hline (i) & $1.65^{\star}$ & \pm & 0.78 & $2.30^{\star \star}$ & \pm & 0.80 & $-2.14^{\star \star}$ & \pm & 0.81 & 0.54 & \pm & 0.81 \\
\hline (j) & $4.02^{\star \star}$ & \pm & 0.85 & $3.42^{\star \star}$ & \pm & 0.85 & 1.02 & \pm & 1.02 & -0.99 & \pm & 1.09 \\
\hline (I) & 1.26 & \pm & 1.63 & $-7.62^{\star \star}$ & \pm & 1.81 & 2.10 & \pm & 1.90 & $-5.89 * \star$ & \pm & 1.91 \\
\hline$\chi^{2}{ }_{(2)}(6 \mathrm{df})$ & $51.93^{\star \star}$ & & & $38.02^{\star \star}$ & & & $159.91^{* *}$ & & & 38.90 ** & & \\
\hline $\mathrm{m}$ & $11.92^{\star \star}$ & \pm & 1.09 & $13.92^{\star \star}$ & \pm & 1.16 & $18.81^{\star \star}$ & \pm & 1.09 & $16.43^{\star \star}$ & \pm & 1.12 \\
\hline (d) & $-7.12^{\star \star}$ & \pm & 1.55 & -1.14 & \pm & 1.57 & $3.01 *$ & \pm & 1.53 & 2.60 & \pm & 1.61 \\
\hline (h) & 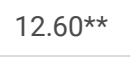 & \pm & 4.09 & 4.45 & \pm & 4.65 & $-10.25^{\star}$ & \pm & 4.29 & 0.83 & \pm & 4.18 \\
\hline (i) & $4.55^{\star \star}$ & \pm & 1.14 & 1.72 & \pm & 1.24 & $-4.27 \star \star$ & \pm & 1.14 & -1.03 & \pm & 1.21 \\
\hline (j) & $16.95^{\star \star}$ & \pm & 3.72 & -1.07 & \pm & 3.83 & $-19.66^{\star \star}$ & \pm & 3.89 & -1.12 & \pm & 4.03 \\
\hline (I) & $-10.56^{\star \star}$ & \pm & 3.60 & -2.77 & \pm & 4.22 & $8.97 *$ & \pm & 3.86 & -0.19 & \pm & 3.66 \\
\hline$(w)$ & $6.50 * \star$ & \pm & 1.55 & 0.40 & \pm & 1.57 & -2.19 & \pm & 1.52 & -3.11 & \pm & 1.60 \\
\hline$(x)$ & $-15.37 \star \star$ & \pm & 3.95 & 3.35 & \pm & 4.53 & 6.10 & \pm & 4.48 & $9.47^{\star}$ & \pm & 4.04 \\
\hline
\end{tabular}




\begin{tabular}{|lllllllllllll|}
$(\mathrm{y})$ & $-8.09^{*}$ & \pm & 3.22 & $8.57 *$ & \pm & 3.37 & $33.20^{\star *}$ & \pm & 3.64 & -6.92 & \pm & 3.85 \\
\hline$(\mathrm{z})$ & $1.52^{*}$ & \pm & 0.60 & -0.58 & \pm & 0.71 & 0.48 & \pm & 0.69 & -0.06 & \pm & 0.65 \\
\hline$\chi^{2}{ }_{(3)}(2 \mathrm{df})$ & $12.81^{\star *}$ & & & $26.75^{\star *}$ & & & $42.77^{\star *}$ & & & $11.22^{\star *}$ & &
\end{tabular}

*, ** Significant at 5 and $1 \%$ levels, respectively

Table 7 Scaling tests and estimation of gene effects for length of primary raceme in four crosses of castor 


\begin{tabular}{|c|c|c|c|c|c|c|c|c|c|c|c|c|}
\hline \multirow{2}{*}{$\begin{array}{l}\text { Scaling tests / gene effects } \\
\text { A }\end{array}$} & \multicolumn{3}{|c|}{ JP 104 x JI 433} & \multicolumn{3}{|c|}{ SKP 84 x JI 433} & \multicolumn{3}{|c|}{ SKP 84 x JI 437} & \multicolumn{3}{|c|}{ SKP 84 x JI 441} \\
\hline & 7.50 & \pm & 3.79 & $-17.70 * \star$ & \pm & 4.01 & 7.67 & \pm & 4.58 & $-39.55^{\star \star}$ & \pm & 5.04 \\
\hline B & $58.74^{\star \star}$ & \pm & 3.16 & $-7.63^{*}$ & \pm & 3.45 & $-12.96^{\star}$ & \pm & 5.36 & -3.82 & \pm & 4.85 \\
\hline C & $-6.73^{*}$ & \pm & 3.18 & -9.02 & \pm & 6.68 & $-16.53^{*}$ & \pm & 6.67 & $-48.98^{\star \star \star}$ & \pm & 8.14 \\
\hline $\mathrm{D}$ & $-36.48 * \star$ & \pm & 2.45 & $8.16^{\star *}$ & \pm & 2.67 & -5.62 & \pm & 3.15 & -2.81 & \pm & 3.31 \\
\hline $\mathrm{B}_{11}$ & -5.88 & \pm & 5.49 & 20.54 & \pm & 10.84 & $81.66^{\star *}$ & \pm & 8.35 & 13.96 & \pm & 15.24 \\
\hline $\mathrm{B}_{12}$ & $9.80 *$ & \pm & 3.83 & $-66.97 * \star$ & \pm & 10.61 & $80.03^{\star *}$ & \pm & 6.47 & $43.12^{\star \star}$ & \pm & 8.05 \\
\hline $\mathrm{B}_{21}$ & $-28.13^{\star \star}$ & \pm & 5.41 & $63.54^{\star *}$ & \pm & 7.19 & $80.59 * *$ & \pm & 6.17 & $87.17^{\star \star}$ & \pm & 7.28 \\
\hline $\mathrm{B}_{22}$ & $-65.46 * \star$ & \pm & 8.24 & 9.00 & \pm & 5.84 & $91.34^{\star *}$ & \pm & 10.98 & $100.12^{\text {** }}$ & \pm & 7.75 \\
\hline $\mathrm{B}_{1 \mathrm{~S}}$ & 10.54 & \pm & 9.69 & $157.03^{\star *}$ & \pm & 14.91 & $201.25^{\star \star}$ & \pm & 14.74 & $-62.59 *$ & \pm & 25.06 \\
\hline $\mathrm{B}_{2 \mathrm{~S}}$ & $-57.17 \star \star$ & \pm & 8.74 & 7.60 & \pm & 10.63 & $197.62^{\star \star}$ & \pm & 19.04 & 143.26 ** & \pm & 14.97 \\
\hline$x$ & $24.37 \star \star$ & \pm & 2.61 & $-29.74 * \star$ & \pm & 3.30 & -2.56 & \pm & 2.51 & $-32.55^{\star \star}$ & \pm & 3.44 \\
\hline Y & $13.25^{\star \star}$ & \pm & 2.74 & $-8.24^{\star}$ & \pm & 3.91 & -3.09 & \pm & 3.00 & 4.05 & \pm & 3.87 \\
\hline \multicolumn{13}{|c|}{ Three parameter model (Cavalli) } \\
\hline $\mathrm{m}$ & $24.34^{\star \star}$ & \pm & 0.46 & $31.13^{\star *}$ & \pm & 0.63 & $29.14^{\star \star}$ & \pm & 0.50 & $30.36^{\star \star}$ & \pm & 0.73 \\
\hline (d) & -0.51 & \pm & 0.47 & 1.10 & \pm & 0.60 & $2.31^{\star *}$ & \pm & 0.46 & $7.95^{\star \star}$ & \pm & 0.62 \\
\hline (h) & $4.86^{\star \star}$ & \pm & 0.87 & $-5.39 \star \star$ & \pm & 1.27 & $-3.02^{\star \star}$ & \pm & 0.98 & -1.63 & \pm & 1.38 \\
\hline$\chi^{2}(1)(9 \mathrm{df})$ & $551.37^{\star * *}$ & & & $423.58^{\star \star}$ & & & $789.03^{\star \star}$ & & & $853.52^{\star \star}$ & & \\
\hline \multicolumn{13}{|c|}{ Six parameter model (Hayman) } \\
\hline $\mathrm{m}$ & $23.77 * *$ & \pm & 0.51 & $34.94^{\star *}$ & \pm & 1.06 & $42.36^{\star \star}$ & \pm & 0.95 & $34.95^{\star \star}$ & \pm & 1.31 \\
\hline (d) & $-23.68 * \star$ & \pm & 2.23 & $7.11^{\star \star}$ & \pm & 1.60 & $11.01 * *$ & \pm & 2.50 & $-18.47 * \star$ & \pm & 2.02 \\
\hline (h) & $79.36^{\star \star}$ & \pm & 5.04 & $-20.88^{\star \star}$ & \pm & 5.92 & -0.86 & \pm & 6.87 & $14.82^{\star}$ & \pm & 7.32 \\
\hline (i) & $72.97 * *$ & \pm & 4.89 & $-16.31^{\star \star}$ & \pm & 5.33 & 11.24 & \pm & 6.30 & 5.61 & \pm & 6.62 \\
\hline (j) & $-25.62^{\star \star}$ & \pm & 2.39 & $-5.03^{*}$ & \pm & 2.18 & $10.31 * \star$ & \pm & 3.32 & $-17.86^{\star \star}$ & \pm & 3.26 \\
\hline$(\mathrm{l})$ & $-39.21 * *$ & \pm & 9.45 & $41.64 * \star$ & \pm & 9.26 & -5.94 & \pm & 12.05 & $37.76^{\star \star}$ & \pm & 11.49 \\
\hline \multicolumn{13}{|c|}{ Digenic and trigenic interactions (Hill) } \\
\hline $\mathrm{m}$ & $7.35^{\star \star}$ & \pm & 2.13 & $27.77^{\star \star}$ & \pm & 2.29 & $27.35^{\star \star}$ & \pm & 2.16 & $68.87^{\star \star}$ & \pm & 2.57 \\
\hline (d) & 0.12 & \pm & 0.74 & $10.61^{\star \star *}$ & \pm & 1.13 & 1.65 & \pm & 0.99 & $27.29 * \star$ & \pm & 1.50 \\
\hline (h) & $58.59 * \star$ & \pm & 6.47 & -3.43 & \pm & 7.47 & -3.22 & \pm & 7.63 & $-129.2^{\star \star}$ & \pm & 7.97 \\
\hline (i) & $16.48^{\star \star}$ & \pm & 2.07 & $7.62^{\star \star}$ & \pm & 2.45 & $3.97^{\star}$ & \pm & 1.95 & $-20.77^{\star \star}$ & \pm & 2.54 \\
\hline (j) & $-7.88^{\star \star}$ & \pm & 2.89 & $-34.66^{\star \star}$ & \pm & 3.55 & 2.43 & \pm & 3.09 & $-55.13^{\star \star}$ & \pm & 4.17 \\
\hline (I) & $-40.49 * *$ & \pm & 4.85 & 7.24 & \pm & 6.57 & 3.16 & \pm & 6.73 & $110.13^{\star \star}$ & \pm & 6.62 \\
\hline$\chi^{2}{ }_{(2)}(6 \mathrm{df})$ & $461.97^{\star *}$ & & & $325.97 * *$ & & & $782.13^{\star \star}$ & & & $326.49 * *$ & & \\
\hline $\mathrm{m}$ & $12.78^{\star \star}$ & \pm & 2.70 & $9.88^{* *}$ & \pm & 3.06 & $5.29 *$ & \pm & 2.66 & $67.21^{\star *}$ & \pm & 3.91 \\
\hline (d) & $20.98^{\star *}$ & \pm & 4.63 & $-44.03^{\star \star}$ & \pm & 4.15 & $-9.07 *$ & \pm & 3.65 & $49.47^{\star \star}$ & \pm & 5.12 \\
\hline (h) & $29.50 \star \star$ & \pm & 9.27 & $79.09 * *$ & \pm & 12.79 & $126.28^{\star \star}$ & \pm & 11.12 & $-108.9 * \star$ & \pm & 15.76 \\
\hline (i) & $9.17 * *$ & \pm & 2.87 & $28.80 * *$ & \pm & 3.57 & $34.21^{\star \star}$ & \pm & 3.60 & $-23.93^{\star \star}$ & \pm & 4.79 \\
\hline (j) & $-137.90 * \star$ & \pm & 14.08 & $136.17 * *$ & \pm & 12.60 & $42.19 * *$ & \pm & 12.09 & -25.25 & \pm & 13.60 \\
\hline (I) & -14.98 & \pm & 7.78 & $-69.73^{\star \star}$ & \pm & 11.98 & $-125.70^{\star \star \star}$ & \pm & 10.26 & $92.42^{\star \star}$ & \pm & 14.35 \\
\hline$(w)$ & $-18.86^{\star \star}$ & \pm & 4.60 & $54.51^{\star \star}$ & \pm & 4.22 & $8.15^{\star}$ & \pm & 3.42 & $-46.96^{\star \star}$ & \pm & 5.31 \\
\hline$(x)$ & $83.35^{\star \star}$ & \pm & 8.35 & $-72.80 \star \star$ & \pm & 13.23 & $-207.80 * \star$ & \pm & 13.43 & -3.88 & \pm & 16.20 \\
\hline
\end{tabular}




\begin{tabular}{|c|c|c|c|c|c|c|c|c|c|c|c|c|}
\hline (y) & $181.14^{* *}$ & \pm & 13.66 & -158.60 ** & \pm & 12.99 & $-58.22 * \star$ & \pm & 12.04 & $-111.70^{\star * *}$ & \pm & 13.03 \\
\hline (z) & 0.73 & \pm & 1.55 & $17.02^{\star \star}$ & \pm & 2.36 & $28.14 * \star$ & \pm & 1.79 & -0.18 & \pm & 2.53 \\
\hline$\chi^{2}{ }_{(3)}(2 \mathrm{df})$ & $146.16^{\star * *}$ & & & $92.84^{\star \star}$ & & & $456.37^{\star \star *}$ & & & $85.59 * \star$ & & \\
\hline
\end{tabular}

*, ** Significant at 5 and $1 \%$ levels, respectively

Table 8 Scaling tests and estimation of gene effects for effective length of primary raceme in four crosses of castor 


\begin{tabular}{|c|c|c|c|c|c|c|c|c|c|c|c|c|}
\hline \multirow{2}{*}{$\begin{array}{l}\text { Scaling tests /gene effects } \\
\text { A }\end{array}$} & \multicolumn{3}{|c|}{ JP 104 x JI 433} & \multicolumn{3}{|c|}{ SKP 84 x JI 433} & \multicolumn{3}{|c|}{ SKP 84 x JI 437} & \multicolumn{3}{|c|}{ SKP 84 x JI 441} \\
\hline & 5.58 & \pm & 3.34 & $-12.20 *$ & \pm & 5.04 & $27.47^{\star \star *}$ & \pm & 4.56 & $-42.45^{\star \star}$ & \pm & 4.68 \\
\hline B & 11.30 ** & \pm & 2.52 & -6.45 & \pm & 4.00 & $13.00^{\star}$ & \pm & 5.26 & $-15.57 * \star$ & \pm & 4.62 \\
\hline C & $11.64^{\star \star}$ & \pm & 4.44 & -8.46 & \pm & 8.01 & 10.75 & \pm & 7.08 & $-67.92^{\star \star}$ & \pm & 7.30 \\
\hline D & -2.62 & \pm & 2.64 & 5.09 & \pm & 3.10 & $-14.86^{\star \star}$ & \pm & 3.47 & -4.95 & \pm & 2.84 \\
\hline $\mathrm{B}_{11}$ & $-11.36^{\star \star}$ & \pm & 3.64 & 16.01 & \pm & 11.01 & $56.54^{\star \star}$ & \pm & 9.67 & 15.68 & \pm & 14.29 \\
\hline $\mathrm{B}_{12}$ & $9.93^{*}$ & \pm & 4.32 & $-75.26^{\star *}$ & \pm & 10.73 & $39.07^{\star *}$ & \pm & 5.55 & $46.03^{\star *}$ & \pm & 7.66 \\
\hline$B_{21}$ & $-23.26^{\star \star}$ & \pm & 5.38 & $23.28^{*}$ & \pm & 9.45 & 36.96 ** & \pm & 5.57 & $95.61^{\star *}$ & \pm & 6.71 \\
\hline$B_{22}$ & $-59.42^{\star \star}$ & \pm & 8.12 & $17.08^{\star \star}$ & \pm & 5.97 & $26.32^{*}$ & \pm & 10.47 & $101.56^{\star \star *}$ & \pm & 8.32 \\
\hline $\mathrm{B}_{1 \mathrm{~s}}$ & -2.18 & \pm & 9.27 & 132.30 ** & \pm & 15.76 & $130.23^{\star *}$ & \pm & 15.88 & -21.34 & \pm & 25.44 \\
\hline $\mathrm{B}_{2 \mathrm{~S}}$ & $-49.27^{\star \star}$ & \pm & 9.15 & 15.24 & \pm & 11.39 & $99.93^{\star *}$ & \pm & 17.78 & $106.22^{\star \star}$ & \pm & 15.35 \\
\hline$x$ & 20.31 ** & \pm & 2.46 & $-24.90 * \star$ & \pm & 3.00 & $8.08^{\star \star}$ & \pm & 2.63 & $-33.86^{\star \star}$ & \pm & 3.34 \\
\hline Y & $14.36^{\star \star}$ & \pm & 2.66 & $-21.27 * \star$ & \pm & 4.12 & -1.71 & \pm & 2.95 & 6.10 & \pm & 3.70 \\
\hline \multicolumn{13}{|c|}{ Three parameter model (Cavalli) } \\
\hline $\mathrm{m}$ & $21.84^{\star \star}$ & \pm & 0.47 & $24.46^{* *}$ & \pm & 0.59 & $26.79 * *$ & \pm & 0.49 & $25.09 * *$ & \pm & 0.73 \\
\hline (d) & -0.28 & \pm & 0.45 & -0.05 & \pm & 0.56 & $2.71^{\star \star}$ & \pm & 0.49 & $4.35^{\star \star}$ & \pm & 0.61 \\
\hline (h) & $3.21 * \star$ & \pm & 0.92 & $5.83^{\star \star}$ & \pm & 1.37 & $-9.65^{\star \star}$ & \pm & 0.89 & 2.32 & \pm & 1.39 \\
\hline$\chi^{2}{ }_{(1)}(9 \mathrm{df})$ & $140.06 * \star$ & & & $310.05^{\star \star}$ & & & $567.65^{\star \star}$ & & & $728.10 * \star$ & & \\
\hline \multicolumn{13}{|c|}{ Six parameter model (Hayman) } \\
\hline $\mathrm{m}$ & $24.31^{\star \star}$ & \pm & 0.94 & $29.92^{\star \star}$ & \pm & 1.19 & $34.25^{\star \star}$ & \pm & 1.20 & $29.01 * \star$ & \pm & 1.08 \\
\hline (d) & -2.28 & \pm & 1.86 & $6.51 * \star$ & \pm & 1.99 & $12.82^{\star \star}$ & \pm & 2.50 & $-14.80 \star \star$ & \pm & 1.84 \\
\hline (h) & 10.39 & \pm & 5.41 & $-20.00 \star \star$ & \pm & 6.99 & 12.93 & \pm & 7.41 & $16.02^{\star}$ & \pm & 6.39 \\
\hline (i) & 5.23 & \pm & 5.28 & -10.19 & \pm & 6.21 & $29.72^{\star \star}$ & \pm & 6.94 & 9.91 & \pm & 5.67 \\
\hline (j) & -2.86 & \pm & 1.97 & -2.87 & \pm & 2.53 & $7.23^{\star}$ & \pm & 3.35 & $-13.44^{\star \star}$ & \pm & 3.09 \\
\hline (l) & $-22.11^{\star}$ & \pm & 8.67 & $28.84^{\star}$ & \pm & 11.29 & $-70.20 \star \star$ & \pm & 12.26 & $48.11^{\star \star}$ & \pm & 10.37 \\
\hline \multicolumn{13}{|c|}{ Digenic and trigenic interactions (Hill) } \\
\hline $\mathrm{m}$ & $18.76^{\star \star}$ & \pm & 2.37 & $22.72^{\star \star}$ & \pm & 2.44 & $13.81^{\star \star}$ & \pm & 1.93 & $57.01^{\star *}$ & \pm & 2.42 \\
\hline (d) & -1.15 & \pm & 0.61 & $7.70^{\star \star}$ & \pm & 1.15 & -1.05 & \pm & 0.99 & $25.34^{\star \star}$ & \pm & 1.49 \\
\hline (h) & $21.37 * \star$ & \pm & 6.51 & -7.44 & \pm & 8.46 & $26.25^{\star \star}$ & \pm & 6.95 & $-108.52^{\star \star}$ & \pm & 7.68 \\
\hline (i) & 0.97 & \pm & 2.38 & $9.76^{\star \star}$ & \pm & 2.56 & 15.08 ** & \pm & 2.01 & $-11.67 \star \star *$ & \pm & 2.19 \\
\hline (j) & 4.26 & \pm & 2.41 & $-25.79 * \star$ & \pm & 3.82 & $14.64^{\star \star}$ & \pm & 2.88 & $-56.39 * \star$ & \pm & 4.12 \\
\hline (l) & $-18.23^{\star *}$ & \pm & 4.78 & $23.10^{* *}$ & \pm & 7.74 & $-25.15^{\star \star}$ & \pm & 6.16 & $97.22^{\star \star}$ & \pm & 6.35 \\
\hline$\chi^{2}{ }_{(2)}(6 \mathrm{df})$ & $106.49 * *$ & & & $237.59 * *$ & & & $482.23^{\star *}$ & & & $254.95^{\star \star}$ & & \\
\hline $\mathrm{m}$ & $16.22^{\star \star}$ & \pm & 3.18 & $8.51^{\star \star}$ & \pm & 3.23 & $11.36^{\star \star}$ & \pm & 2.51 & 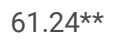 & \pm & 4.42 \\
\hline (d) & 0.90 & \pm & 4.99 & $-33.18^{\star \star}$ & \pm & 4.11 & -4.53 & \pm & 3.42 & $36.35^{\star \star}$ & \pm & 6.17 \\
\hline (h) & $27.62^{\star}$ & \pm & 12.04 & $61.59 \star *$ & \pm & 14.05 & $116.19 * *$ & \pm & 11.86 & $-113.68^{\star \star}$ & \pm & 16.12 \\
\hline (i) & 2.72 & \pm & 3.27 & $28.99 * *$ & \pm & 3.73 & $26.89 * \star$ & \pm & 3.48 & $-17.74^{\star \star \star}$ & \pm & 5.19 \\
\hline (j) & $-47.20 \star \star$ & \pm & 13.60 & $101.02^{\star \star}$ & \pm & 13.08 & 23.76 & \pm & 12.46 & -1.57 & \pm & 15.34 \\
\hline (l) & $-24.45^{\star}$ & \pm & 10.63 & $-40.98 * \star$ & \pm & 13.34 & $-118.18^{\star \star}$ & \pm & 11.41 & $100.77^{\star \star}$ & \pm & 13.96 \\
\hline$(w)$ & -0.26 & \pm & 4.98 & $42.12^{\star \star}$ & \pm & 4.12 & 6.00 & \pm & 3.19 & $-34.64 \star \star$ & \pm & 6.24 \\
\hline$(x)$ & 14.29 & \pm & 12.00 & $-53.52^{\star \star}$ & \pm & 14.59 & $-119.29 * \star$ & \pm & 15.24 & 12.29 & \pm & 15.04 \\
\hline
\end{tabular}




\begin{tabular}{|c|c|c|c|c|c|c|c|c|c|c|c|c|}
\hline (y) & 90.84 ** & \pm & 12.95 & -122.46 ** & \pm & 13.35 & -20.19 & \pm & 12.51 & -122.06 ** & \pm & 13.60 \\
\hline (z) & $4.80 *$ & \pm & 1.88 & $3.17^{\star *}$ & \pm & 2.59 & $21.07 * \star$ & \pm & 1.98 & -0.10 & \pm & 2.36 \\
\hline$\chi_{(3)}^{2}(2 \mathrm{df})$ & 3.71 & & & $76.57^{\star \star *}$ & & & $362.35^{\star \star}$ & & & $56.03^{\star \star}$ & & \\
\hline
\end{tabular}

*, ** Significant at 5 and $1 \%$ levels, respectively

Table 9 Scaling tests and estimation of gene effects for number of effective branches per plant in four crosses of castor 


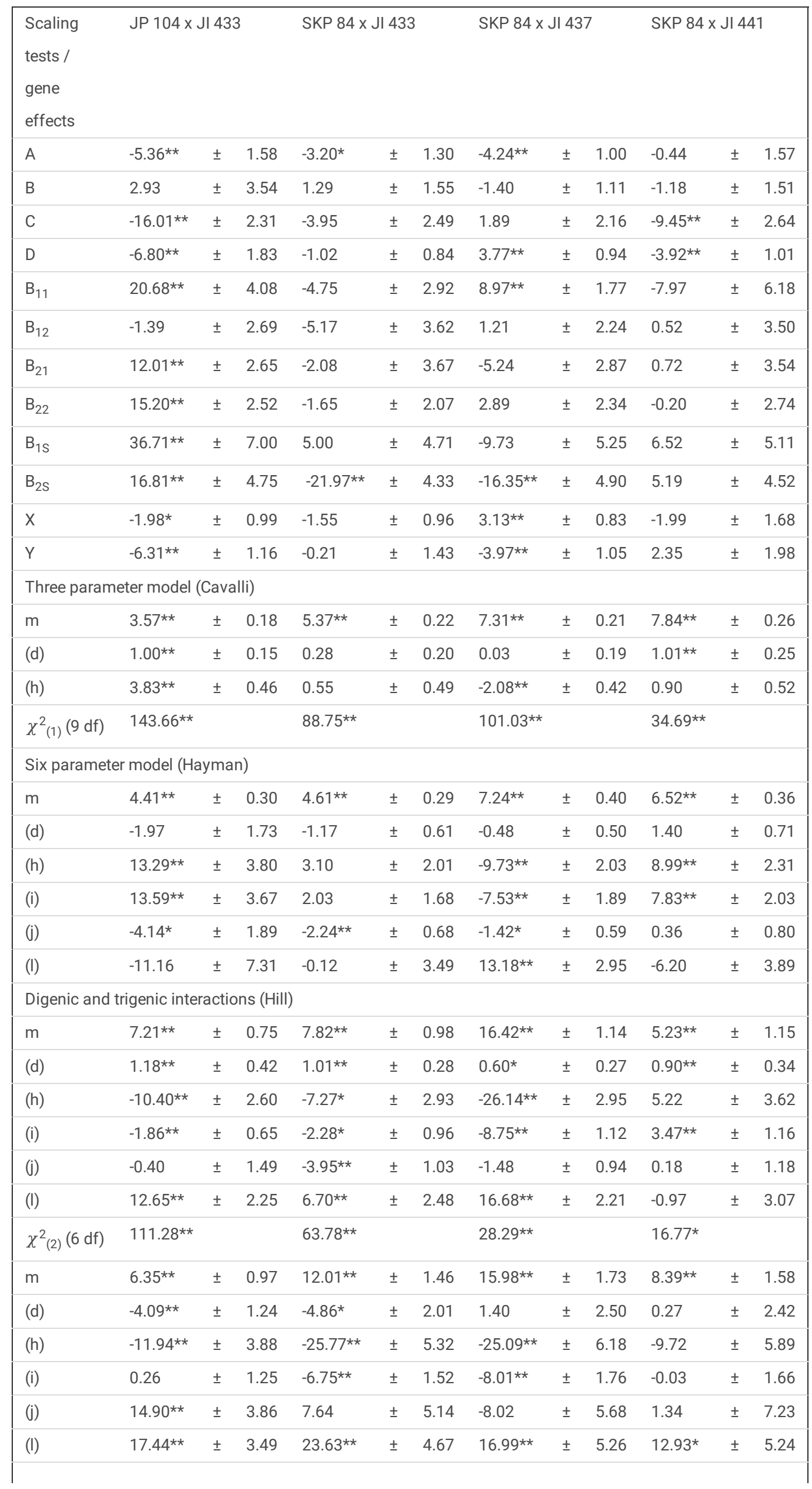




\begin{tabular}{|c|c|c|c|c|c|c|c|c|c|c|c|c|}
\hline (w) & $4.61^{\star \star}$ & \pm & 1.19 & $6.04 * \star$ & \pm & 2.01 & -0.37 & \pm & 2.50 & 0.77 & \pm & 2.42 \\
\hline$(x)$ & $11.92^{\star \star}$ & \pm & 4.23 & $20.22^{\star \star}$ & \pm & 4.16 & 0.81 & \pm & 5.39 & $17.80 * \star$ & \pm & 4.90 \\
\hline (y) & $-17.83^{\star \star}$ & \pm & 4.30 & -4.23 & \pm & 5.02 & $11.86^{*}$ & \pm & 4.65 & 1.35 & \pm & 6.88 \\
\hline (z) & $-4.27 * \star$ & \pm & 0.69 & $-2.17 \star$ & \pm & 0.90 & $-1.92^{*}$ & \pm & 0.80 & -1.73 & \pm & 1.09 \\
\hline$\chi^{2}{ }_{(3)}(2 \mathrm{df})$ & $31.15^{\star \star}$ & & & $26.63^{\star \star}$ & & & 9.36 ** & & & 2.93 & & \\
\hline
\end{tabular}

*, ** Significant at 5 and $1 \%$ levels, respectively

Table 10 Scaling tests and estimation of gene effects for number of capsules on primary raceme in four crosses of castor 


\begin{tabular}{|c|c|c|c|c|c|c|c|c|c|c|c|c|}
\hline $\begin{array}{l}\text { Scaling tests / } \\
\text { gene } \\
\text { effects }\end{array}$ & \multicolumn{3}{|c|}{ JP 104 x JI 433} & \multicolumn{3}{|c|}{ SKP 84 x JI 433} & \multicolumn{3}{|c|}{ SKP 84 x JI 437} & \multicolumn{3}{|c|}{ SKP 84 x JI 441} \\
\hline A & 18.20 & \pm & 14.46 & $112.82^{\star \star}$ & \pm & 17.24 & $-46.96 * \star$ & \pm & 7.15 & 17.71 & \pm & 10.06 \\
\hline B & $-38.04 * \star$ & \pm & 11.65 & $55.51^{\star *}$ & \pm & 12.54 & 10.51 & \pm & 7.38 & $24.93^{\star \star}$ & \pm & 8.62 \\
\hline C & 3.45 & \pm & 20.43 & 32.47 & \pm & 20.98 & $36.40^{\star}$ & \pm & 14.28 & 10.55 & \pm & 9.78 \\
\hline D & 11.65 & \pm & 9.20 & $-67.93^{\star \star}$ & \pm & 11.06 & $36.42^{\star \star}$ & \pm & 6.27 & $-16.05^{\star}$ & \pm & 7.53 \\
\hline $\mathrm{B}_{11}$ & -27.67 & \pm & 25.29 & 6.47 & \pm & 17.93 & $57.53^{\star \star}$ & \pm & 15.82 & $-37.19 * \star$ & \pm & 12.15 \\
\hline $\mathrm{B}_{12}$ & 26.00 & \pm & 21.12 & $-113.09 * *$ & \pm & 28.81 & 13.72 & \pm & 16.02 & 0.53 & \pm & 11.30 \\
\hline$B_{21}$ & $-39.91^{\star}$ & \pm & 20.03 & $-73.19 *$ & \pm & 27.97 & $72.39 * *$ & \pm & 14.54 & $36.92^{\star \star}$ & \pm & 11.13 \\
\hline$B_{22}$ & 44.77 & \pm & 26.45 & $-53.79 * \star$ & \pm & 16.88 & $-59.69 * \star$ & \pm & 12.34 & $54.29 * *$ & \pm & 13.25 \\
\hline $\mathrm{B}_{1 \mathrm{~S}}$ & $120.49 * *$ & \pm & 45.47 & $91.37 * \star$ & \pm & 30.00 & -43.81 & \pm & 28.14 & $-199.99 * *$ & \pm & 27.54 \\
\hline $\mathrm{B}_{2 \mathrm{~S}}$ & 18.68 & \pm & 46.58 & $-236.89 * *$ & \pm & 29.41 & $-96.29 * \star$ & \pm & 26.33 & $-90.39 * \star$ & \pm & 23.29 \\
\hline$x$ & -1.63 & \pm & 7.29 & 5.09 & \pm & 7.41 & $14.64^{\star \star}$ & \pm & 4.88 & $-31.97 * \star$ & \pm & 5.20 \\
\hline Y & -7.75 & \pm & 9.26 & $-34.74^{\star \star}$ & \pm & 10.80 & $22.07 * \star$ & \pm & 6.29 & 5.09 & \pm & 5.63 \\
\hline \multicolumn{13}{|c|}{ Three parameter model (Cavalli) } \\
\hline $\mathrm{m}$ & $77.43^{\star \star}$ & \pm & 1.96 & $91.05^{\star \star}$ & \pm & 1.48 & $72.31^{\star \star}$ & \pm & 1.33 & $94.86^{\star \star}$ & \pm & 1.09 \\
\hline (d) & $5.46^{\star \star}$ & \pm & 1.81 & $-11.21 * \star$ & \pm & 1.43 & 1.65 & \pm & 1.18 & $6.25^{\star \star}$ & \pm & 1.10 \\
\hline (h) & $7.47 *$ & \pm & 3.59 & $28.20 * *$ & \pm & 3.88 & 3.08 & \pm & 2.78 & $-20.19 * \star$ & \pm & 2.09 \\
\hline$\chi_{(1)}^{2}(9 \mathrm{df})$ & $76.77^{\star \star}$ & & & $162.71^{\star *}$ & & & $172.41 * \star$ & & & 125.31 ** & & \\
\hline \multicolumn{13}{|c|}{ Six parameter model (Hayman) } \\
\hline $\mathrm{m}$ & $83.68^{\star \star}$ & \pm & 3.29 & $99.46^{\star \star}$ & \pm & 3.31 & $86.53^{\star \star}$ & \pm & 2.64 & $85.58^{\star \star}$ & \pm & 2.07 \\
\hline (d) & $23.88^{\star \star}$ & \pm & 6.42 & $26.82^{\star \star}$ & \pm & 8.85 & $-12.33^{\star \star}$ & \pm & 3.36 & -1.44 & \pm & 6.28 \\
\hline (h) & -29.33 & \pm & 19.99 & $130.63^{\star \star}$ & \pm & 23.57 & $-49.84^{\star \star}$ & \pm & 13.42 & 18.46 & \pm & 15.29 \\
\hline (i) & -23.29 & \pm & 18.41 & $135.86^{\star \star}$ & \pm & 22.12 & $-72.84 * \star$ & \pm & 12.54 & $32.09 *$ & \pm & 15.07 \\
\hline (j) & $28.12^{\star \star}$ & \pm & 8.35 & $28.65^{\star \star}$ & \pm & 9.10 & $-28.73^{\star \star}$ & \pm & 4.30 & -3.61 & \pm & 6.45 \\
\hline (l) & 43.14 & \pm & 32.84 & $-304.20 * \star$ & \pm & 41.17 & $109.28 * \star$ & \pm & 19.62 & $-74.74 * *$ & \pm & 26.99 \\
\hline \multicolumn{13}{|c|}{ Digenic and trigenic interactions (Hill) } \\
\hline $\mathrm{m}$ & $69.40^{\star \star}$ & \pm & 7.80 & $69.45^{\star \star}$ & \pm & 7.98 & $111.21^{\star \star}$ & \pm & 5.51 & $133.60^{\star *}$ & \pm & 6.83 \\
\hline (d) & $-11.07 * \star$ & \pm & 3.38 & -6.16 ** & \pm & 1.95 & $14.31^{\star \star}$ & \pm & 2.10 & $5.66^{\star \star *}$ & \pm & 1.34 \\
\hline (h) & 18.96 & \pm & 24.80 & $110.38^{\star \star *}$ & \pm & 25.57 & $-87.92^{\star \star}$ & \pm & 16.03 & $-107.68^{\star \star}$ & \pm & 18.85 \\
\hline (i) & 13.64 & \pm & 7.65 & $21.42^{\star \star}$ & \pm & 7.90 & $-41.69 * \star$ & \pm & 5.49 & $-41.25^{\star \star}$ & \pm & 6.81 \\
\hline (j) & $55.99 \star \star$ & \pm & 9.76 & $-42.77^{\star \star \star}$ & \pm & 9.20 & $-54.43^{\star \star}$ & \pm & 6.84 & 0.89 & \pm & 6.42 \\
\hline (I) & -4.01 & \pm & 21.07 & $-76.42^{\star \star}$ & \pm & 21.78 & $58.09 * *$ & \pm & 13.07 & $47.80^{* *}$ & \pm & 13.36 \\
\hline$\chi^{2}{ }_{(2)}(6 \mathrm{df})$ & $39.95^{\star *}$ & & & $122.39 * *$ & & & $40.06^{* *}$ & & & $80.86^{* *}$ & & \\
\hline $\mathrm{m}$ & $54.38^{\star \star}$ & \pm & 10.04 & $79.16^{\star \star}$ & \pm & 10.27 & $105.99 * *$ & \pm & 7.66 & 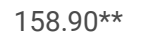 & \pm & 9.15 \\
\hline (d) & $-81.46 * \star$ & \pm & 14.12 & $-108.05^{\star \star}$ & \pm & 13.30 & $52.35^{\star \star}$ & \pm & 10.29 & 9.10 & \pm & 13.89 \\
\hline (h) & $92.66^{*}$ & \pm & 40.32 & 52.49 & \pm & 41.90 & -51.46 & \pm & 31.17 & $-215.04 * *$ & \pm & 32.39 \\
\hline (i) & $33.54^{\star \star}$ & \pm & 11.75 & 13.93 & \pm & 10.54 & $-39.90^{\star \star *}$ & \pm & 8.25 & $-69.48^{\star *}$ & \pm & 9.28 \\
\hline (j) & $205.92^{\star \star}$ & \pm & 40.03 & $165.51^{\star \star}$ & \pm & 36.87 & -156.51 ** & \pm & 25.87 & 61.91 & \pm & 34.67 \\
\hline (l) & $-73.12^{\star \star}$ & \pm & 36.69 & -11.65 & \pm & 38.59 & 16.15 & \pm & 28.49 & $141.34^{\star \star}$ & \pm & 27.54 \\
\hline$(w)$ & $76.02^{\star \star}$ & \pm & 13.84 & $105.41^{\star \star}$ & \pm & 13.24 & $-35.87 \star \star$ & \pm & 10.26 & -7.06 & \pm & 13.87 \\
\hline
\end{tabular}

Page 23/33 


\begin{tabular}{|c|c|c|c|c|c|c|c|c|c|c|c|c|}
\hline$(x)$ & $-92.94 *$ & \pm & 43.55 & $122.52^{\star \star}$ & \pm & 40.80 & $-64.42^{\star}$ & \pm & 31.76 & $129.37^{\star \star}$ & \pm & 29.42 \\
\hline (y) & $-89.17 *$ & \pm & 37.03 & -42.81 & \pm & 38.14 & $89.86^{\star *}$ & \pm & 24.37 & $-122.59 * \star$ & \pm & 29.98 \\
\hline (z) & 8.41 & \pm & 6.33 & $-36.96 * \star$ & \pm & 7.48 & 18.50 ** & \pm & 4.87 & $-9.86^{*}$ & \pm & 4.64 \\
\hline$\chi_{(3)}^{2}(2 \mathrm{df})$ & 4.30 & & & $27.44^{\star \star}$ & & & 0.05 & & & $16.90 * *$ & & \\
\hline
\end{tabular}

*, ** Significant at 5 and $1 \%$ levels, respectively

Table 11 Scaling tests and estimation of gene effects for shelling out turn in four crosses of castor 


\begin{tabular}{|c|c|c|c|c|c|c|c|c|c|c|c|c|}
\hline \multirow{2}{*}{$\begin{array}{l}\text { Scaling tests / } \\
\text { gene effects } \\
\text { A }\end{array}$} & \multicolumn{3}{|c|}{ JP 104 x JI 433} & \multicolumn{3}{|c|}{ SKP 84 x JI 433} & \multicolumn{3}{|c|}{ SKP 84 x JI 437} & \multicolumn{3}{|c|}{ SKP 84 x JI 441} \\
\hline & $33.46^{* *}$ & \pm & 2.03 & $17.22^{\star \star}$ & \pm & 3.59 & $-48.38 * \star$ & \pm & 4.02 & $-12.79 \star \star *$ & \pm & 2.97 \\
\hline B & $43.69 \star \star$ & \pm & 2.57 & -1.64 & \pm & 3.34 & $-46.31 * \star$ & \pm & 3.75 & $-19.26 * \star$ & \pm & 2.48 \\
\hline C & $100.61^{\star *}$ & \pm & 4.91 & $27.67^{\star \star}$ & \pm & 6.24 & 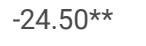 & \pm & 7.25 & $-39.12^{\star \star}$ & \pm & 4.36 \\
\hline D & $11.73^{\star \star}$ & \pm & 1.97 & $6.04^{\star *}$ & \pm & 1.87 & $35.09 * *$ & \pm & 1.23 & $-3.54^{\star \star}$ & \pm & 1.09 \\
\hline $\mathrm{B}_{11}$ & $-90.60 * \star$ & \pm & 4.65 & 16.39 & \pm & 8.91 & 5.77 & \pm & 7.37 & $-55.54 \star \star$ & \pm & 6.82 \\
\hline $\mathrm{B}_{12}$ & -7.61 & \pm & 5.17 & -2.12 & \pm & 7.37 & -11.11 & \pm & 10.01 & $-47.89 * *$ & \pm & 5.78 \\
\hline$B_{21}$ & $-58.45^{\star \star}$ & \pm & 5.06 & -9.81 & \pm & 7.62 & $30.35^{\star \star}$ & \pm & 9.90 & $-79.33^{\star \star}$ & \pm & 6.44 \\
\hline $\mathrm{B}_{22}$ & $36.52^{\star \star}$ & \pm & 4.62 & $58.40^{\star \star}$ & \pm & 5.80 & $40.61^{\star *}$ & \pm & 6.59 & $-15.23^{\star *}$ & \pm & 3.52 \\
\hline $\mathrm{B}_{1 \mathrm{~S}}$ & -101.70 ** & \pm & 5.76 & -23.86 & \pm & 14.52 & $138.69 * \star$ & \pm & 12.95 & -96.81 ** & \pm & 11.89 \\
\hline $\mathrm{B}_{2 \mathrm{~S}}$ & $50.16^{\star \star}$ & \pm & 9.32 & $217.98^{\star *}$ & \pm & 10.62 & 7.25 & \pm & 11.70 & -5.35 & \pm & 6.44 \\
\hline$x$ & $-19.07 * \star$ & \pm & 1.42 & $-8.58 \star \star$ & \pm & 2.06 & $-19.07 * \star$ & \pm & 1.70 & -2.22 & \pm & 1.57 \\
\hline Y & -2.99 & \pm & 2.12 & $-21.68^{\star \star}$ & \pm & 3.05 & -6.79 & \pm & 3.62 & $-14.11 \star \star$ & \pm & 2.36 \\
\hline \multicolumn{13}{|c|}{ Three parameter model (Cavalli) } \\
\hline $\mathrm{m}$ & $56.38^{\star \star}$ & \pm & 0.35 & $45.94^{\star \star}$ & \pm & 0.46 & $46.23^{\star \star}$ & \pm & 0.34 & $60.79 * *$ & \pm & 0.32 \\
\hline (d) & $2.19 \star \star$ & \pm & 0.33 & $14.14^{\star \star}$ & \pm & 0.39 & $2.81^{\star \star}$ & \pm & 0.31 & $1.48^{\star *}$ & \pm & 0.27 \\
\hline (h) & $11.39 * \star$ & \pm & 0.67 & $17.65^{\star \star}$ & \pm & 0.96 & $21.80 * \star$ & \pm & 0.67 & $-15.81 * *$ & \pm & 0.76 \\
\hline$\chi^{2}{ }_{(1)}(9 \mathrm{df})$ & $1934.68^{* *}$ & & & $1745.18^{\star \star}$ & & & $3228.79 * \star$ & & & $3845.57 * *$ & & \\
\hline \multicolumn{13}{|c|}{ Six parameter model (Hayman) } \\
\hline $\mathrm{m}$ & $78.90 \star \star$ & \pm & 0.86 & $64.01 * \star$ & \pm & 0.76 & $60.70 * \star$ & \pm & 0.49 & $42.05^{\star \star}$ & \pm & 0.28 \\
\hline (d) & $-15.19 * \star$ & \pm & 0.94 & $10.87^{\star \star}$ & \pm & 1.08 & $1.75^{\star}$ & \pm & 0.73 & -0.44 & \pm & 0.93 \\
\hline (h) & $-23.08^{\star *}$ & \pm & 4.32 & $-18.15^{\star \star}$ & \pm & 4.63 & $-50.15^{\star \star}$ & \pm & 4.27 & 1.08 & \pm & 3.04 \\
\hline (i) & $-23.45^{\star \star}$ & \pm & 3.95 & $-12.08^{\star \star}$ & \pm & 3.74 & $-70.18 * \star$ & \pm & 2.47 & $7.07 * \star$ & \pm & 2.19 \\
\hline (j) & $-5.11 \star \star$ & \pm & 1.20 & $9.42^{\star \star}$ & \pm & 1.86 & -1.03 & \pm & 1.56 & $3.23^{\star}$ & \pm & 1.48 \\
\hline (l) & $-53.70 * \star$ & \pm & 6.21 & -3.49 & \pm & 7.60 & $164.87 * \star$ & \pm & 7.82 & $24.97 * \star$ & \pm & 5.74 \\
\hline \multicolumn{13}{|c|}{ Digenic and trigenic interactions (Hill) } \\
\hline $\mathrm{m}$ & $46.05^{\star \star}$ & \pm & 1.40 & $14.31^{\star \star}$ & \pm & 1.54 & $77.46^{\star *}$ & \pm & 1.33 & $69.04 * *$ & \pm & 1.14 \\
\hline (d) & $-1.49 * *$ & \pm & 0.57 & $17.83^{\star \star}$ & \pm & 0.90 & $4.12^{\star \star}$ & \pm & 0.70 & $11.08^{\star \star}$ & \pm & 0.64 \\
\hline (h) & 75.06 ** & \pm & 4.61 & $106.09 \star \star$ & \pm & 5.61 & $-122.15^{\star \star}$ & \pm & 4.90 & $-89.43^{\star \star}$ & \pm & 4.16 \\
\hline (i) & -0.12 & \pm & 1.41 & $33.22^{\star \star}$ & \pm & 1.40 & $-8.14^{\star \star}$ & \pm & 1.23 & 13.60 ** & \pm & 0.97 \\
\hline (j) & $14.32^{\star \star}$ & \pm & 1.66 & -3.91 & \pm & 2.55 & -8.51 ** & \pm & 1.99 & $-30.82^{\star *}$ & \pm & 2.12 \\
\hline (l) & $-69.63^{\star \star}$ & \pm & 4.06 & $-66.15^{\star \star}$ & \pm & 5.24 & $143.38^{\star \star *}$ & \pm & 4.67 & $92.77 * \star$ & \pm & 3.91 \\
\hline$\chi^{2}{ }_{(2)}(6 \mathrm{df})$ & $1227.58^{\star *}$ & & & $1156.62^{\star *}$ & & & 2228.14 ** & & & $2249.53^{\star \star}$ & & \\
\hline $\mathrm{m}$ & $8.77^{\star \star}$ & \pm & 2.26 & 12.46 ** & \pm & 2.45 & $80.01^{\star \star}$ & \pm & 2.10 & $90.29 \star \star$ & \pm & 1.67 \\
\hline (d) & 4.42 & \pm & 2.87 & $60.81^{\star \star}$ & \pm & 2.98 & $-59.97 * \star$ & \pm & 2.27 & $28.65^{\star \star}$ & \pm & 2.00 \\
\hline (h) & $262.64^{\star \star *}$ & \pm & 9.84 & 205.20 ** & \pm & 10.13 & -108.96 ** & \pm & 8.62 & $-182.26^{\star \star}$ & \pm & 6.28 \\
\hline (i) & $42.84^{\star \star}$ & \pm & 2.45 & $50.62^{* *}$ & \pm & 3.08 & $-12.01 * \star$ & \pm & 2.81 & $-17.05^{\star \star}$ & \pm & 2.15 \\
\hline (j) & 50.30 ** & \pm & 7.80 & $-39.27 \star \star$ & \pm & 9.03 & $153.63^{\star \star}$ & \pm & 7.45 & $-86.01^{\star \star}$ & \pm & 6.32 \\
\hline (I) & $-247.18^{\star \star}$ & \pm & 9.21 & -171.26 ** & \pm & 9.36 & 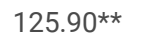 & \pm & 8.00 & $180.86^{\star \star}$ & \pm & 5.63 \\
\hline (w) & $-12.04^{\star *}$ & \pm & 2.85 & $-63.68^{\star \star}$ & \pm & 3.00 & $65.13^{\star *}$ & \pm & 2.22 & -16.70 ** & \pm & 1.93 \\
\hline$(x)$ & $-210.99 * *$ & \pm & 9.97 & $-146.70 * *$ & \pm & 9.90 & $-89.65^{\star \star}$ & \pm & 7.61 & $125.46^{* \star}$ & \pm & 5.40 \\
\hline
\end{tabular}




\begin{tabular}{|c|c|c|c|c|c|c|c|c|c|c|c|c|}
\hline (y) & $-87.86^{\star *}$ & \pm & 7.33 & $-54.10 * \star$ & \pm & 9.15 & $-126.43^{\star *}$ & \pm & 7.70 & $73.41^{\star \star}$ & \pm & 7.03 \\
\hline (z) & $22.13^{\star \star}$ & \pm & 1.60 & $6.67 \star \star$ & \pm & 1.79 & $33.04 * \star$ & \pm & 1.52 & $-13.98^{\star *}$ & \pm & 1.17 \\
\hline$\chi_{(3)}^{2}(2 \mathrm{df})$ & $692.94 * \star$ & & & $152.66^{\star \star}$ & & & 625.26 ** & & & $466.27^{\star \star}$ & & \\
\hline
\end{tabular}

*, ** Significant at 5 and $1 \%$ levels, respectively

Table 12 Scaling tests and estimation of gene effects for 100 seed weight in four crosses of castor 


\begin{tabular}{|c|c|c|c|c|c|c|c|c|c|c|c|c|}
\hline \multirow{2}{*}{$\begin{array}{l}\text { Scaling tests /gene effects } \\
\text { A }\end{array}$} & \multicolumn{3}{|c|}{ JP 104 x JI 433} & \multicolumn{3}{|c|}{ SKP 84 x JI 433} & \multicolumn{3}{|c|}{ SKP 84 x JI 437} & \multicolumn{3}{|c|}{ SKP 84 x JI 441} \\
\hline & 1.92 & \pm & 1.53 & $3.66^{\star *}$ & \pm & 1.10 & -1.78 & \pm & 1.51 & 0.75 & \pm & 2.34 \\
\hline B & 0.34 & \pm & 1.78 & $-3.11 * \star$ & \pm & 0.75 & $-2.92^{\star}$ & \pm & 1.28 & $-6.82^{\star \star}$ & \pm & 1.75 \\
\hline C & -3.48 & \pm & 2.68 & 1.74 & \pm & 2.95 & $-8.44^{\star \star}$ & \pm & 2.23 & $7.71 *$ & \pm & 3.60 \\
\hline D & $-2.87 * \star$ & \pm & 0.96 & 0.60 & \pm & 1.42 & -1.87 & \pm & 1.08 & $6.89 \star \star$ & \pm & 1.66 \\
\hline $\mathrm{B}_{11}$ & -1.21 & \pm & 3.22 & $-12.28 * \star$ & \pm & 2.33 & 6.20 & \pm & 3.23 & $-10.70 \star \star$ & \pm & 3.18 \\
\hline $\mathrm{B}_{12}$ & 5.13 & \pm & 3.19 & 0.97 & \pm & 2.81 & 3.46 & \pm & 2.58 & $12.74 \star \star$ & \pm & 3.81 \\
\hline $\mathrm{B}_{21}$ & $14.22^{\star *}$ & \pm & 3.20 & $-18.63^{\star \star}$ & \pm & 2.32 & -8.68 ** & \pm & 2.63 & $8.39 *$ & \pm & 3.92 \\
\hline $\mathrm{B}_{22}$ & $17.57^{\star \star}$ & \pm & 3.21 & -2.94 & \pm & 1.98 & -0.65 & \pm & 2.87 & -18.60 ** & \pm & 4.15 \\
\hline $\mathrm{B}_{1 \mathrm{~S}}$ & -10.01 & \pm & 5.35 & $-35.73^{\star \star}$ & \pm & 5.03 & $23.10^{\star \star}$ & \pm & 5.39 & -4.75 & \pm & 5.97 \\
\hline $\mathrm{B}_{2 \mathrm{~S}}$ & 1.23 & \pm & 6.58 & $-30.68^{* *}$ & \pm & 6.51 & $-17.03^{\star *}$ & \pm & 5.86 & $18.15^{\star \star}$ & \pm & 5.06 \\
\hline$x$ & $-6.97 * \star$ & \pm & 0.87 & $2.56^{\star \star}$ & \pm & 0.96 & $4.75^{\star \star}$ & \pm & 1.09 & $3.12^{\star}$ & \pm & 1.20 \\
\hline Y & 0.75 & \pm & 1.30 & -0.61 & \pm & 1.09 & $-2.69 *$ & \pm & 1.19 & $12.55^{\star \star}$ & \pm & 1.67 \\
\hline \multicolumn{13}{|c|}{ Three parameter model (Cavalli) } \\
\hline $\mathrm{m}$ & $34.22^{\star \star}$ & \pm & 0.22 & $33.96^{* *}$ & \pm & 0.20 & $33.43^{* *}$ & \pm & 0.26 & $33.72^{\star \star}$ & \pm & 0.28 \\
\hline (d) & $0.49 *$ & \pm & 0.21 & $1.56^{\star \star}$ & \pm & 0.18 & $-0.87^{\star \star}$ & \pm & 0.26 & $2.44^{\star \star}$ & \pm & 0.27 \\
\hline (h) & $-2.08 * \star$ & \pm & 0.43 & $-1.36 * \star$ & \pm & 0.41 & 0.59 & \pm & 0.52 & $2.24^{\star \star}$ & \pm & 0.57 \\
\hline$\chi_{(1)}^{2}(9 \mathrm{df})$ & $219.51^{\star \star}$ & & & $199.92^{\star \star}$ & & & $104.03^{\star \star}$ & & & $138.01^{\star \star}$ & & \\
\hline \multicolumn{13}{|c|}{ Six parameter model (Hayman) } \\
\hline $\mathrm{m}$ & $33.56^{\star \star}$ & \pm & 0.33 & $32.53^{\star \star}$ & \pm & 0.67 & $32.34^{\star \star}$ & \pm & 0.40 & $37.93^{\star \star}$ & \pm & 0.63 \\
\hline (d) & -0.91 & \pm & 0.69 & $2.97 \star \star$ & \pm & 0.46 & 0.89 & \pm & 0.72 & $4.15^{\star \star}$ & \pm & 1.08 \\
\hline (h) & $6.29 \star \star$ & \pm & 2.25 & -1.65 & \pm & 2.90 & 2.82 & \pm & 2.30 & $-7.57^{\star}$ & \pm & 3.57 \\
\hline (i) & $5.74 * \star$ & \pm & 1.92 & -1.19 & \pm & 2.84 & 3.74 & \pm & 2.17 & $-13.70 \star \star$ & \pm & 3.33 \\
\hline (j) & 0.79 & \pm & 0.96 & $3.38^{* *}$ & \pm & 0.55 & 0.57 & \pm & 0.93 & $3.78 * \star$ & \pm & 1.21 \\
\hline (l) & $-8.00 *$ & \pm & 3.87 & 0.65 & \pm & 3.48 & 0.95 & \pm & 3.64 & $19.84^{\star \star}$ & \pm & 5.62 \\
\hline \multicolumn{13}{|c|}{ Digenic and trigenic interactions (Hill) } \\
\hline $\mathrm{m}$ & $37.62^{\star \star}$ & \pm & 0.90 & 39.60 ** & \pm & 1.32 & $31.51^{\star \star}$ & \pm & 1.03 & $29.56^{\star \star}$ & \pm & 1.20 \\
\hline (d) & $2.07 * \star$ & \pm & 0.41 & -0.39 & \pm & 0.27 & $-1.82^{\star \star}$ & \pm & 0.46 & 0.88 & \pm & 0.45 \\
\hline (h) & $-8.72^{\star \star}$ & \pm & 3.06 & -11.50 ** & \pm & 3.14 & 3.01 & \pm & 3.05 & $15.27^{\star \star}$ & \pm & 3.97 \\
\hline (i) & $-4.80 * \star$ & \pm & 0.85 & $-7.07 \star \star$ & \pm & 1.33 & $3.02 \star \star$ & \pm & 1.04 & $4.21 \star \star$ & \pm & 1.22 \\
\hline (j) & $-6.43^{\star \star}$ & \pm & 1.16 & $9.08^{\star \star}$ & \pm & 0.96 & $4.44^{\star *}$ & \pm & 1.53 & $5.42^{\star \star}$ & \pm & 1.45 \\
\hline (I) & 3.16 & \pm & 2.72 & $4.54^{\star}$ & \pm & 2.15 & 0.04 & \pm & 2.34 & $-10.18^{\star \star}$ & \pm & 3.45 \\
\hline$\chi^{2}{ }_{(2)}(6 \mathrm{df})$ & 146.54 ** & & & 78.64 ** & & & $79.91^{\star \star}$ & & & $113.27^{\star *}$ & & \\
\hline $\mathrm{m}$ & $40.10 \star \star *$ & \pm & 1.37 & $43.58^{\star *}$ & \pm & 2.05 & $36.82^{\star *}$ & \pm & 1.45 & $28.50 \star * \star$ & \pm & 1.57 \\
\hline (d) & $-7.09 * \star$ & \pm & 1.86 & -0.81 & \pm & 2.97 & $-12.12^{\star \star}$ & \pm & 2.15 & $8.49 \star \star$ & \pm & 2.17 \\
\hline (h) & $-19.65^{\star \star}$ & \pm & 5.18 & $-29.68^{\star \star}$ & \pm & 7.93 & $-16.53^{\star \star}$ & \pm & 5.43 & $30.22^{\star \star}$ & \pm & 6.93 \\
\hline (i) & $-7.34^{\star *}$ & \pm & 1.57 & $-10.78^{\star \star}$ & \pm & 2.07 & -1.52 & \pm & 1.60 & $4.65^{\star \star}$ & \pm & 1.71 \\
\hline (j) & $30.63^{\star \star}$ & \pm & 4.87 & 1.14 & \pm & 6.51 & $13.91^{*}$ & \pm & 5.66 & $-14.55^{\star}$ & \pm & 6.64 \\
\hline (I) & $12.76^{\star \star}$ & \pm & 4.57 & $20.97^{\star \star}$ & \pm & 7.07 & $17.34^{\star \star}$ & \pm & 4.77 & $-28.30 \star \star$ & \pm & 6.54 \\
\hline$(w)$ & $4.94^{\star \star}$ & \pm & 1.84 & 0.83 & \pm & 2.97 & $12.67^{\star \star}$ & \pm & 2.14 & $-8.31^{\star *}$ & \pm & 2.16 \\
\hline$(x)$ & $13.83^{\star *}$ & \pm & 4.76 & $18.17^{* *}$ & \pm & 7.92 & $14.62^{\star \star}$ & \pm & 5.49 & $-30.90 * *$ & \pm & 7.52 \\
\hline
\end{tabular}




\begin{tabular}{|c|c|c|c|c|c|c|c|c|c|c|c|c|}
\hline (y) & $-38.07 * \star$ & \pm & 4.33 & $18.29 * *$ & \pm & 5.22 & $13.93^{*}$ & \pm & 5.53 & 9.23 & \pm & 6.46 \\
\hline (z) & -0.88 & \pm & 0.78 & $-2.27^{\star}$ & \pm & 1.11 & $-3.45^{\star \star}$ & \pm & 0.87 & 9.96 ** & \pm & 1.19 \\
\hline$\chi^{2}{ }_{(3)}(2 \mathrm{df})$ & $48.88^{\star \star *}$ & & & $56.66^{\star *}$ & & & $6.33^{\star}$ & & & $26.55^{\star \star}$ & & \\
\hline
\end{tabular}

*, ** Significant at 5 and $1 \%$ levels, respectively

Table 13 Scaling tests and estimation of gene effects for seed yield per plant in four crosses of castor 


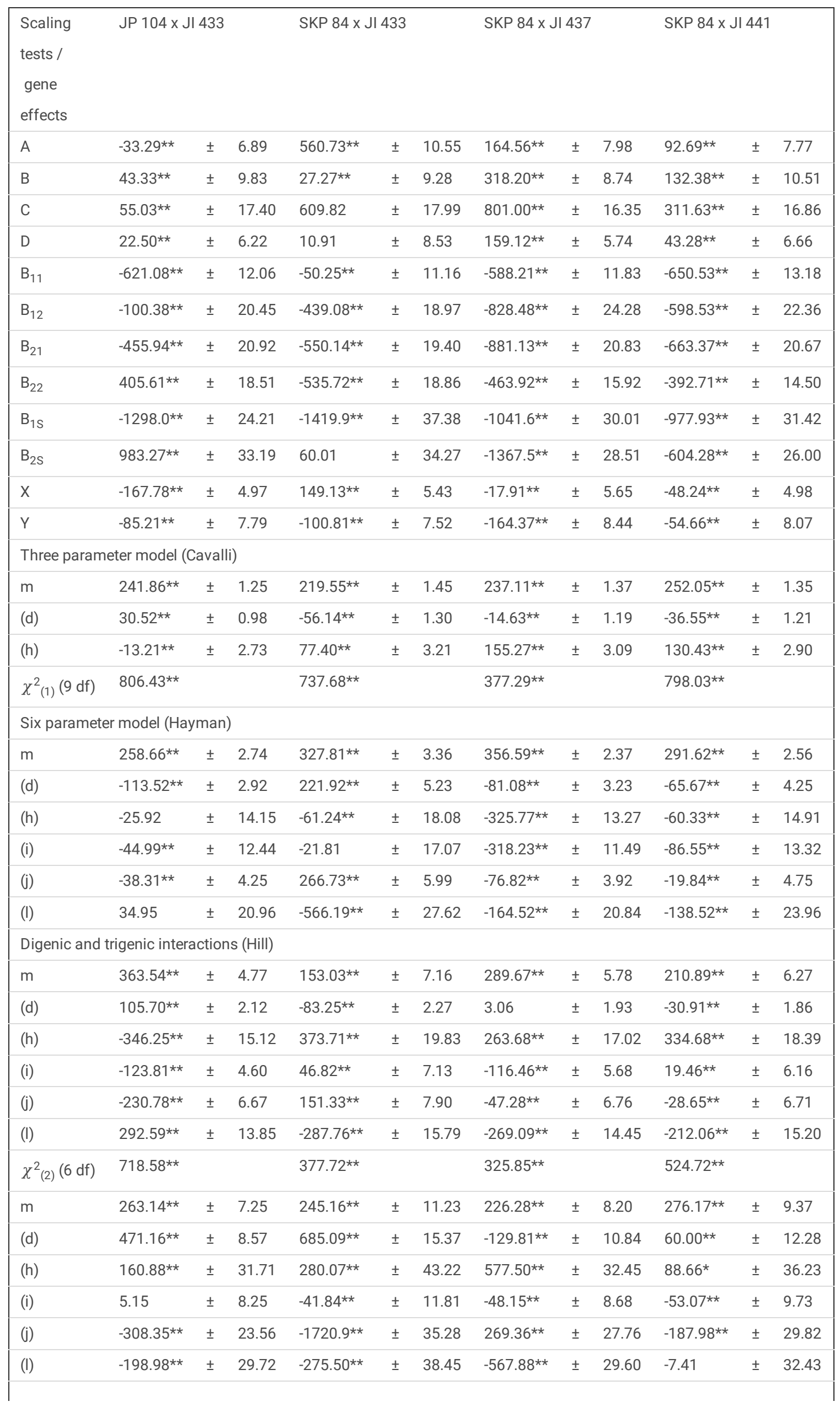

Page 29/33 


\begin{tabular}{|c|c|c|c|c|c|c|c|c|c|c|c|c|}
\hline$(w)$ & $-522.36 * \star$ & \pm & 8.42 & $-744.61^{\star *}$ & \pm & 15.28 & $132.21^{\star \star}$ & \pm & 10.79 & $-95.45^{\star \star}$ & \pm & 12.24 \\
\hline$(x)$ & $-712.22^{\star \star}$ & \pm & 31.51 & -66.17 & \pm & 42.80 & $-362.91 * \star$ & \pm & 29.90 & $141.72^{\star \star}$ & \pm & 31.96 \\
\hline (y) & $-871.94 * \star$ & \pm & 24.38 & $1471.37 * \star$ & \pm & 30.39 & $-225.69 * *$ & \pm & 28.03 & 52.75 & \pm & 27.12 \\
\hline (z) & $171.64^{\star \star}$ & \pm & 4.52 & $-84.07 * \star$ & \pm & 6.31 & $40.03^{\star \star}$ & \pm & 5.08 & $28.91^{\star \star}$ & \pm & 5.38 \\
\hline$\chi_{(3)}^{2}(2 \mathrm{df})$ & $700.96 * \star$ & & & $250.24^{\star \star}$ & & & $295.70 * \star$ & & & $431.65^{\star \star}$ & & \\
\hline
\end{tabular}

*, ** Significant at 5 and $1 \%$ levels, respectively

Table 14 Scaling tests and estimation of gene effects for oil content in four crosses of castor 


\begin{tabular}{|c|c|c|c|c|c|c|c|c|c|c|c|c|}
\hline \multirow{2}{*}{$\begin{array}{l}\text { Scaling tests /gene effects } \\
\text { A }\end{array}$} & \multicolumn{3}{|c|}{ JP 104 x JI 433} & \multicolumn{3}{|c|}{ SKP 84 x JI 433} & \multicolumn{3}{|c|}{ SKP 84 x JI 437} & \multicolumn{3}{|c|}{ SKP 84 x JI 441} \\
\hline & 0.52 & \pm & 0.31 & $-2.34^{\star \star}$ & \pm & 0.45 & -0.44 & \pm & 0.27 & -1.88 & \pm & 1.33 \\
\hline B & $2.83^{\star *}$ & \pm & 0.31 & $-2.02^{\star \star}$ & \pm & 0.31 & $1.14^{\star \star}$ & \pm & 0.20 & 3.51 ** & \pm & 0.31 \\
\hline C & $3.51 * *$ & \pm & 0.49 & -0.49 & \pm & 0.73 & $-1.85^{\star \star}$ & \pm & 0.47 & $1.13^{*}$ & \pm & 0.47 \\
\hline D & 0.08 & \pm & 0.19 & $1.93^{\star *}$ & \pm & 0.29 & $-1.28^{\star \star}$ & \pm & 0.19 & -0.25 & \pm & 0.66 \\
\hline $\mathrm{B}_{11}$ & $-6.88 * \star$ & \pm & 0.69 & $-5.42^{\star \star}$ & \pm & 0.82 & 0.08 & \pm & 1.24 & $-1.88^{\star *}$ & \pm & 0.43 \\
\hline $\mathrm{B}_{12}$ & $-3.82^{\star \star}$ & \pm & 0.41 & $9.45^{\star \star}$ & \pm & 0.89 & $-4.35^{\star \star}$ & \pm & 0.50 & -4.68 ** & \pm & 0.73 \\
\hline$B_{21}$ & $2.76^{\star \star}$ & \pm & 0.51 & $5.00 * \star$ & \pm & 0.80 & $-4.99 \star \star$ & \pm & 0.54 & $-3.61^{\star *}$ & \pm & 0.68 \\
\hline $\mathrm{B}_{22}$ & $5.37 \star \star$ & \pm & 1.08 & $8.42^{\star \star}$ & \pm & 0.55 & -0.39 & \pm & 0.38 & $1.10^{*}$ & \pm & 0.48 \\
\hline $\mathrm{B}_{1 \mathrm{~S}}$ & $-14.36^{\star \star}$ & \pm & 1.24 & $-5.82^{\star \star}$ & \pm & 1.36 & $7.34^{\star *}$ & \pm & 0.93 & -9.03 ** & \pm & 0.71 \\
\hline $\mathrm{B}_{2 \mathrm{~S}}$ & $-7.33^{\star \star}$ & \pm & 1.51 & $11.91^{\star \star}$ & \pm & 1.08 & $3.95^{\star \star}$ & \pm & 0.85 & $-6.19 \star \star$ & \pm & 0.96 \\
\hline $\mathrm{x}$ & $-4.71^{\star *}$ & \pm & 0.27 & $-2.35^{\star \star}$ & \pm & 0.22 & 0.28 & \pm & 0.31 & $-1.01^{\star \star}$ & \pm & 0.15 \\
\hline Y & 0.11 & \pm & 0.28 & $2.86^{\star \star}$ & \pm & 0.32 & $-2.26^{\star \star}$ & \pm & 0.35 & $-1.88^{\star \star}$ & \pm & 0.26 \\
\hline \multicolumn{13}{|c|}{ Three parameter model (Cavalli) } \\
\hline $\mathrm{m}$ & $48.44^{\star \star}$ & \pm & 0.05 & $47.62^{\star \star}$ & \pm & 0.05 & $47.12^{\star \star}$ & \pm & 0.05 & $48.34^{\star \star}$ & \pm & 0.04 \\
\hline (d) & $0.21 * *$ & \pm & 0.04 & $1.23^{* *}$ & \pm & 0.04 & $-0.19 * \star$ & \pm & 0.04 & $0.67^{* *}$ & \pm & 0.03 \\
\hline (h) & $0.27 * \star$ & \pm & 0.09 & $-0.52^{\star \star}$ & \pm & 0.12 & $0.94 * \star$ & \pm & 0.09 & $-1.67 * \star$ & \pm & 0.08 \\
\hline$\chi^{2}{ }_{(1)}(9 \mathrm{df})$ & 834.30 ** & & & $613.83^{\star *}$ & & & $405.57 * \star$ & & & $739.34^{\star \star}$ & & \\
\hline \multicolumn{13}{|c|}{ Six parameter model (Hayman) } \\
\hline $\mathrm{m}$ & $48.46^{\star \star}$ & \pm & 0.07 & $48.04^{\star \star}$ & \pm & 0.11 & $46.95^{\star \star}$ & \pm & 0.08 & $47.16^{\star \star}$ & \pm & 0.03 \\
\hline (d) & $-1.25^{\star \star}$ & \pm & 0.11 & $-0.75^{\star \star}$ & \pm & 0.16 & $-0.41^{\star \star}$ & \pm & 0.10 & $-2.43^{\star \star}$ & \pm & 0.66 \\
\hline (h) & $1.46^{\star \star}$ & \pm & 0.42 & $-2.36 * \star$ & \pm & 0.64 & $1.33^{* *}$ & \pm & 0.42 & -1.92 & \pm & 1.34 \\
\hline (i) & -0.16 & \pm & 0.37 & $-3.86^{\star \star}$ & \pm & 0.58 & $2.55^{\star \star}$ & \pm & 0.38 & 0.50 & \pm & 1.32 \\
\hline (j) & $-1.15^{\star \star}$ & \pm & 0.21 & -0.15 & \pm & 0.21 & $-0.78^{\star \star}$ & \pm & 0.13 & $-2.69 \star \star$ & \pm & 0.66 \\
\hline$(\mathrm{l})$ & $-3.19 * \star$ & \pm & 0.68 & $8.22^{\star *}$ & \pm & 0.98 & $-3.25^{\star \star}$ & \pm & 0.63 & -2.13 & \pm & 2.68 \\
\hline \multicolumn{13}{|c|}{ Digenic and trigenic interactions (Hill) } \\
\hline $\mathrm{m}$ & $48.61^{\star \star}$ & \pm & 0.16 & $48.25^{\star \star}$ & \pm & 0.19 & $44.99 * *$ & \pm & 0.19 & $49.27^{\star \star}$ & \pm & 0.18 \\
\hline (d) & $2.09 * *$ & \pm & 0.11 & $1.42^{\star \star}$ & \pm & 0.09 & $0.27^{\star \star}$ & \pm & 0.08 & $0.72^{\star \star}$ & \pm & 0.06 \\
\hline (h) & 0.92 & \pm & 0.50 & $-2.89 \star \star$ & \pm & 0.67 & $5.57^{\star \star}$ & \pm & 0.56 & $-4.15^{\star \star}$ & \pm & 0.60 \\
\hline (i) & $-1.12^{\star \star}$ & \pm & 0.17 & $-0.46^{\star *}$ & \pm & 0.18 & 2.80 ** & \pm & 0.20 & $-1.07 * \star$ & \pm & 0.16 \\
\hline (j) & $-5.63^{\star \star}$ & \pm & 0.30 & -0.90 ** & \pm & 0.32 & -0.38 & \pm & 0.22 & $-0.56^{*}$ & \pm & 0.23 \\
\hline (I) & -1.37 ** & \pm & 0.40 & $2.16^{\star \star}$ & \pm & 0.63 & $-2.57 * \star$ & \pm & 0.46 & $1.65^{\star \star}$ & \pm & 0.53 \\
\hline$\chi^{2}{ }_{(2)}(6 \mathrm{df})$ & $414.53^{\star *}$ & & & $597.11^{\star *}$ & & & $188.12^{\star \star}$ & & & $681.01^{\text {*x }}$ & & \\
\hline $\mathrm{m}$ & $49.53^{\star \star}$ & \pm & 0.21 & $46.87^{\star \star \star}$ & \pm & 0.26 & $45.46^{\star \star}$ & \pm & 0.26 & $49.52^{\star \star}$ & \pm & 0.23 \\
\hline (d) & 0.23 & \pm & 0.33 & $0.84^{\star \star}$ & \pm & 0.31 & $1.37^{\star \star *}$ & \pm & 0.38 & 0.24 & \pm & 0.29 \\
\hline (h) & $-2.59 * \star$ & \pm & 0.84 & $4.96^{\star *}$ & \pm & 1.24 & $3.62^{\star *}$ & \pm & 1.03 & $-6.28 * \star$ & \pm & 0.84 \\
\hline (i) & $-3.03^{\star *}$ & \pm & 0.30 & 0.55 & \pm & 0.31 & $2.62^{\star *}$ & \pm & 0.28 & $-1.51^{\star \star}$ & \pm & 0.25 \\
\hline (j) & $5.75^{\star \star}$ & \pm & 1.10 & $8.16^{\star \star}$ & \pm & 0.94 & $-6.61 * \star$ & \pm & 1.14 & $2.48^{\star \star}$ & \pm & 0.79 \\
\hline (I) & 0.85 & \pm & 0.77 & $-5.44 \star \star$ & \pm & 1.21 & -0.17 & \pm & 0.95 & $4.45^{\star \star}$ & \pm & 0.73 \\
\hline$(w)$ & 0.09 & \pm & 0.33 & $-1.18^{\star \star}$ & \pm & 0.30 & $-0.96^{*}$ & \pm & 0.38 & 0.09 & \pm & 0.28 \\
\hline$(x)$ & $5.40 \star \star$ & \pm & 1.03 & $-8.46^{\star \star}$ & \pm & 1.42 & 0.37 & \pm & 1.01 & $10.13^{\star \star *}$ & \pm & 0.61 \\
\hline
\end{tabular}




\begin{tabular}{|c|c|c|c|c|c|c|c|c|c|c|c|c|}
\hline (y) & $-15.09 * \star$ & \pm & 1.18 & $-15.87 \star \star$ & \pm & 0.98 & $7.60 \star \star$ & \pm & 1.12 & $-4.60^{\star \star}$ & \pm & 0.75 \\
\hline (z) & $0.55^{\star *}$ & \pm & 0.14 & $1.92^{\star *}$ & \pm & 0.22 & $-2.02^{\star *}$ & \pm & 0.19 & $-2.58^{\star *}$ & \pm & 0.14 \\
\hline$\chi^{2}{ }_{(3)}(2 \mathrm{df})$ & $116.76^{\star \star}$ & & & $226.92^{\star *}$ & & & $23.16^{* *}$ & & & $94.08^{\star \star}$ & & \\
\hline Type of epistasis & Duplicate & & & Duplicate & & & Duplicate & & & Duplicate & & \\
\hline
\end{tabular}

*, ** Significant at 5 and $1 \%$ levels, respectively

\section{Figures}

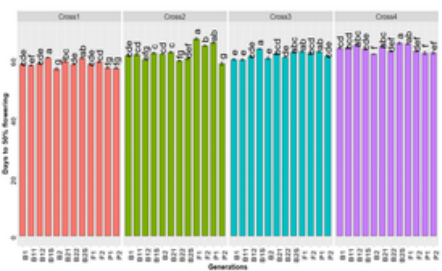

(a)

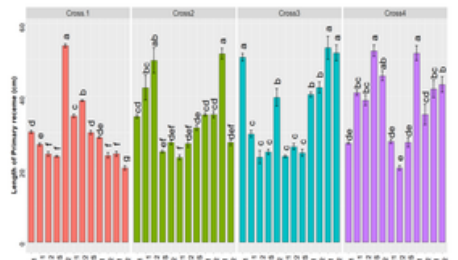

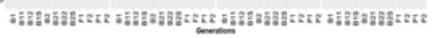

(e)

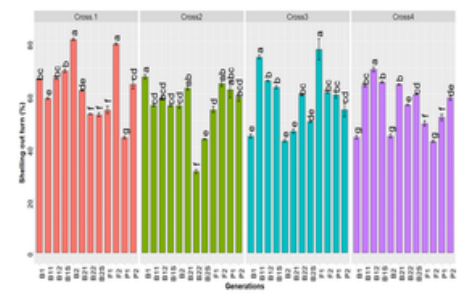

(i)

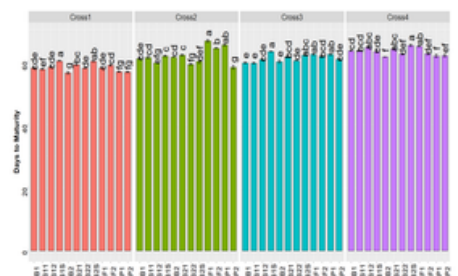

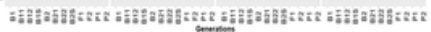

(b)

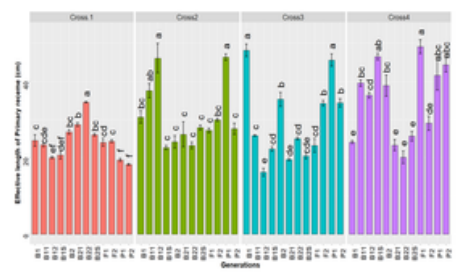

(f)

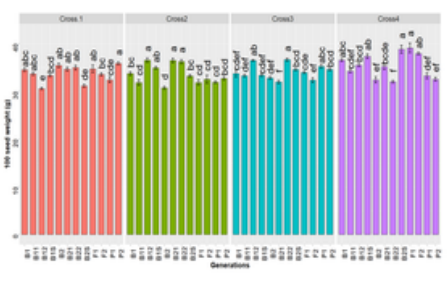

(j)

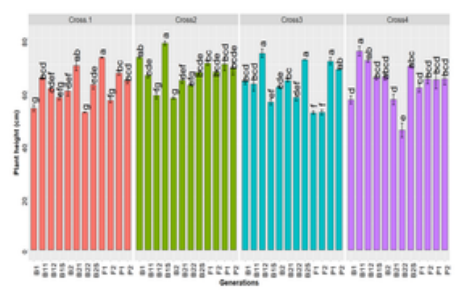

(c)

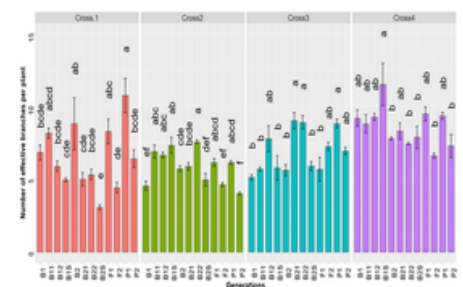

(g)

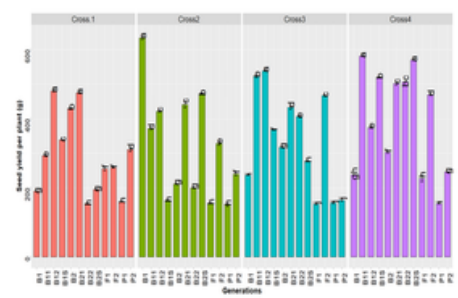

(k)

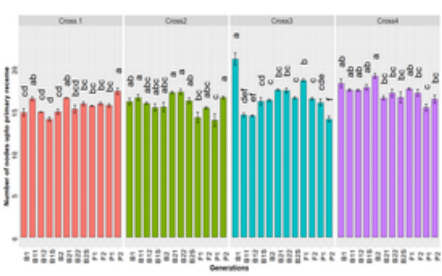

(d)

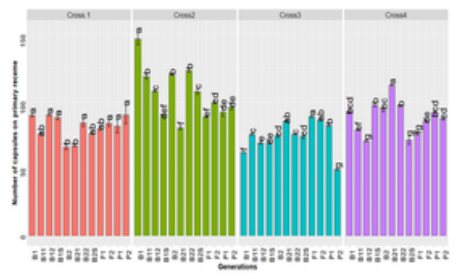

(h)

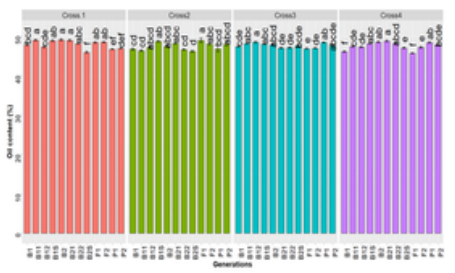

(1)

\section{Figure 1}

a Per se performance and error bars (same letter depict no significant differences while different letters showing significant differences at $5 \%$ ) for days to $50 \%$ flowering in 4 crosses of castor Cross $1=\mathrm{JP} 104$ x JI 433, Cross 2= SKP 84 x JI 433, Cross 3= SKP 84 x JI 437, Cross 4= SKP 84 x JI 441 b Per se performance and error bars (same letter depict no significant differences while different letters showing significant differences at $5 \%$ ) for days to maturity of primary raceme in 4 crosses of castor Cross $1=\mathrm{JP} 104$ x JI 433, Cross 2= SKP 84 x JI 433, Cross 3= SKP 84 x JI 437, Cross $4=$ SKP 84 x JI 441 c Per se performance and error bars (same letter depict no significant differences while different letters showing significant differences at $5 \%$ ) for plant height up to primary raceme $(\mathrm{cm})$ in 4 crosses of castor Cross $1=\mathrm{JP} 104$ x JI 433, Cross 2= SKP 84 x JI 433, Cross 3= SKP 84 x JI 437, Cross 4= SKP 84 x JI $441 \mathrm{~d}$ Per se performance and error bars (same letter depict no significant differences while different letters showing significant differences at $5 \%$ ) for number of nodes up to primary raceme in 4 crosses of castor Cross $1=$ JP 104 x JI 433, Cross 2= SKP 84 x JI 433, Cross 3= SKP 84 x JI 437, Cross $4=$ SKP 84 x JI 441 e Per se performance and error bars (same letter depict no significant differences while different letters showing significant differences at $5 \%$ ) for length of primary raceme (cm) in 4 crosses of castor Cross 1 = JP 104 x JI 433, Cross 2= SKP 84 x JI 433, Cross 3= SKP 84 x JI 437, Cross 4= SKP 84 x JI 441 f Per se performance and error bars (same letter depict no significant differences while different letters showing significant differences at $5 \%$ ) for effective length of primary raceme (cm) in $4 \mathrm{crosses}$ of castor Cross 1 = JP 104 x JI 433, Cross 2= SKP 84 x JI 433, Cross 3= SKP 84 x JI 437, Cross 4= SKP 84 x JI 441 h Per se performance and error bars (same letter depict no significant differences while different letters showing significant differences at $5 \%$ ) for number of capsules on primary raceme in 4 crosses of castor Cross1 = JP 104 x JI 433, Cross 2= SKP 84 x JI 433, Cross 3= SKP 84 x JI 437, Cross 4= SKP 84 x JI 441 i Per se performance and error bars (same letter depict no significant differences while different letters showing significant differences at $5 \%$ ) for shelling out turn (\%) in 4 crosses of castor Cross $1=$ JP $104 \mathrm{x}$ JI 433, Cross 2= SKP 84 x JI 433, Cross 3= SKP 84 x JI 437, Cross 4= SKP 84 x JI 441 j Per se performance and error bars (same letter depict no significant differences while different letters showing significant differences at 5\%) for 100 seed weight (g) in 4 crosses of castor Cross $1=$ JP $104 \times$ JI 433 , Cross $2=$ SKP 84 x JI 433, Cross 3= SKP 84 x JI 437, Cross 4= SKP 84 x JI 441 k Per se performance and error bars (same letter depict no significant differences while different letters showing significant differences at 5\%) for seed yield per plant (g) in 4 crosses of castor Cross $1=\mathrm{JP} 104$ x JI 433 , Cross $2=\mathrm{SKP} 84 \times \mathrm{JI} 433$, Cross $3=$ SKP 84 x JI 437, Cross 4= SKP 84 x JI 441 I Per se performance and error bars (same letter depict no significant differences while different letters 
showing significant differences at 5\%) for oil content (\%) in 4 crosses of castor Cross $1=\mathrm{JP} 104 \times \mathrm{JI} 433$, Cross $2=\mathrm{SKP} 84 \times \mathrm{JI} 433$, Cross $3=\mathrm{SKP} 84 \times \mathrm{JI} 437$, Cross 4= SKP 84 x JI 441 